Graduate Theses, Dissertations, and Problem Reports

2021

The Well-Made Man: An Exploration of George Tesman in Henrik Ibsen's Hedda Gabler

Ryan Ernst

Follow this and additional works at: https://researchrepository.wvu.edu/etd

Part of the Acting Commons, Dramatic Literature, Criticism and Theory Commons, Performance Studies Commons, and the Theatre History Commons 


\title{
The Well-Made Man: \\ An Exploration of George Tesman in Henrik Ibsen's Hedda Gabler
}

\author{
Ryan Ernst \\ Thesis submitted \\ to the School of Theatre \& Dance \\ at West Virginia University \\ In partial fulfillment of the requirements for the degree of \\ Master of Fine Arts in \\ Acting
}

Jay Malarcher, Ph.D., Chair

Jerry McGonigle, M.F.A.

Cornel Gabara, M.F.A.

School of Theatre \& Dance

Morgantown, West Virginia

2021

Keywords: Theatre, Acting, Hedda Gabler, George Tesman, Realism, Well-Made, Henrik Ibsen Copyright 2021 Ryan Ernst 


\begin{abstract}
The Well-Made Man: An Exploration of George Tesman in Henrik Ibsen's Hedda Gaber
\end{abstract}

\author{
Ryan Ernst
}

Hedda Gabler is one of the best-known works of Realism theatre, and the character, Hedda, is a showcase of dynamic and challenging work; but her husband, George Tesman, rarely, if ever, is showcased. Here I explain why George's character deserves more attention and actually makes for a better protagonist than Hedda. Textual analysis shows the absence of the play's parental figures and a rubber band metaphor illustrates how all the characters are con-nected to each other. The misconceptions and subtext concerning George: a social filtering mechanism, perception of character, George's selflessness, how he is made fun of, the heart compared to the mind, George's supposed obliviousness, whether George truly loves Hedda, Hedda as "The Other," George's doing vs. Hedda's undoing, and George's treatment of others, when uncovered elevate George's character status within the literary context of the play. Then, detailing a personal process for playing the role of George in a production: how to deal with the traditional aspects of performance, the language and translation, being a student during the production, which acting tools best serve me the show, and dealing with unfortunate circum-stances such as illness and the onset of the COVID-19 pandemic, George is shown to be a challenging role in its own right. 


\section{Table of Contents}

ACT I - The Play $\quad 1$

Curtain Speech - The Introduction $\quad 1$

$\begin{array}{ll}\text { The Father of Realism } & 4\end{array}$

First Impressions of George Tesman 12

Textual Analysis and Observations: Where are the Parents? 17

$\begin{array}{ll}\text { The Rubber Band Theory } & 20\end{array}$

Perceptions - Misdirection and Subtext: The Great Filter 22

Character is in the Eye of the Beholder 23

George's Selflessness $\quad 25$

The Butt of the Joke $\quad 27$

The Heart vs. the Head $\quad 30$

Oblivious or Oh, Blivious $\quad 32$

The Question of Love $\quad 34$

The "Other" $\quad 38$

Doing vs. Undoing $\quad 39$

George as a Humanitarian $\quad 41$

George's Connections $\quad 43$

Making Strong Choices $\quad 45$

$\begin{array}{ll}\text { ACT II - The Show } & 47\end{array}$

$\begin{array}{ll}\text { The Great Pretender } & 47\end{array}$

$\begin{array}{ll}\text { Looking Back } & 49\end{array}$

Driving the Plot $\quad 52$

Dealing With Odd Language $\quad 54$

$\begin{array}{ll}\text { Traditional Staging } & 56\end{array}$

The Struggle with the Translation $\quad 59$

The Student Experience $\quad 62$

$\begin{array}{ll}\text { Acting Tools } & 67\end{array}$

Dealing with Unfortunate Circumstances $\quad 76$

$\begin{array}{ll}\text { COVID-19 } & 78\end{array}$

$\begin{array}{ll}\text { Struggling With a Character } & 79\end{array}$

$\begin{array}{ll}\text { Conclusion } & 81\end{array}$

Bibliography $\quad 83$ 


\section{ACT I - The Play}

\section{Curtain Speech - The Introduction}

\section{"Let me begin with a sort of introduction." -Rosmersholm}

Say the name Hedda Gabler, and most people with at least a limited knowledge of drama or literature of the modern era and beyond will have heard it before. "The ice queen who neglects her husband and then kills herself, right?" Yes. Well, no ... a touch more complicated than that, but sure. Ask to whom the name George Tesman belongs, and you will probably receive more blank stares than nods; or perhaps a, "that sounds familiar ..." followed by an, "oh yeah" once provided with the answer. George Tesman is Hedda Gabler's husband, a single point in the triumvirate of men who influence Hedda's life, and so much more; a scholar, a loving nephew, a soon-to-be-father, and an all-around upstanding guy. Great, case closed, mystery solved, we can all rest soundly now that we know everything about this one, George Tesman, right? Sure, if we feel content with living a lie.

George Tesman deserves a revelation of the human beneath the husband and the depth of his modern make-up. George plays an important role, not only in this play, but in Theatre Arts as a whole, particularly for the time in which Hedda was written. The catalogue of dramatic studies contain, and justly so, a great deal of writing which focuses on the character of Hedda, but, unjustly so, relatively little observation of George. Ibsen did not write George merely as Hedda's one-dimensional husband; he wrote George in all three dimensions: a man with purpose and one with a character arc that, dramatically, bests that of Hedda herself. George makes a great lens with which to view the world of Hedda Gabler, certainly for someone tasked with portraying the role in a production, but also for anyone else curious enough to see the world around the titular 
character from another point of view. Ibsen wrote depth into George's character and would not want his importance to go unobserved. He was far too deliberate in his writing and character construction, particularly with this play, to have accidentally created a character with so many layers. "Of all Ibsen's work, Hedda Gabler is the most detached, the most objective-a character study pure and simple" (Archer 6). Indeed, every character in the story has more depth and impact than many give them credit for, but naturally, Hedda, the titular character, takes the spotlight. George Tesman, however, remains universally underrated, underanalyzed, and underappreciated, but George, in fact, makes a more convincing protagonist than Hedda.

\section{Synopsis}

\section{“The story goes, and many believe it -" -The Vikings at Helgeland}

For those unfamiliar with Hedda Gabler, the play centers around the titular character, a woman who finds herself restless and unhappy, caught in the middle of a trifecta of men all vying for her attention. Furthermore, she feels tied down by a family she cares little for, and she suffers from an idleness and dissipation that drives her to devastating consequences. George Tesman, Hedda's new husband, is a kind, happy, scholarly man who would rather spend time researching than conversing, and whose meek temperament belies his emotional prowess. The play opens with Hedda and George returning home from their six-month long honeymoon - which seemed to Hedda more of a research expedition than a romantic excursion. They have just purchased a brand-new house with the financial help of their friend Judge Brack, whose interest in Hedda seems to extend beyond friendly support, on the condition that once George gains a new professorial appointment at the university, he can afford to repay Judge 
Brack the money which he borrowed. George revels in the prospect of this new chapter in his life, as does his Aunt Juliana, who raised George from a young boy, and strives to maintain a close relationship; but Hedda, on the other hand, seems much less excited by her present position. Between the financial burdens limiting her desired lifestyle, the abundance of shared time with "Auntie Juli," and the overall feeling of stuck in a less-than romanticized life she detests, Hedda does not see her future especially optimistically. Her anxieties compound when some old friends reenter the couple's life. Thea Elvsted, an old classmate of Hedda and an old flame of George, shows up asking for assistance in locating her friend and business partner, Eilert Lovborg, who just so happens to be an old friend of George's and an old flame of Hedda's. Through Thea's conversation with the Tesman's she reveals that, despite some trouble with his addictive tendencies and a resulting fall from grace in the public eye some years prior, Eilert now walks the straight and narrow and has written a fantastic new book that will set him back on track for success. Eilert's new book also puts him in a position to compete with George for a professorship position at a local university. George sends Eilert a letter asking him to visit and Lovborg eventually makes his way to the Tesman household where he shows George his brand-new manuscript, while simultaneously setting his mind at ease about competing for the university appointment. While George's worries cool, Hedda's heart burns. She sees the reintroduction of her past poetic lover as an invitation for excitement among the drabness of her life with George.

Brack is holding a party at his house in celebration of George's new appointment and, after some persuasion from the men and malevolent manipulation from Hedda, Lovborg decides to join the men at the party. After a night of revelry that unsurprisingly leads to relapse, Lovborg, in his drunken stupor, manages to lose his one, and only, copy of his new, revolutionary 
manuscript. Luckily for him, George finds it and intends to return it once Eilert sobers up; unluckily for him, George's Aunt Rina falls terribly ill and George leaves the manuscript in the care of Hedda ... who promptly burns it up in the stove, destroying it. Believing his manuscript lost to his own negligence, Eilert falls into a deep despair, resulting in him shooting himself with a pistol that Hedda gave to him hours before, and shortly succumbing to his injury. Judge Brack, is privy to all local legal, and once he receives the news of Eilert's escapades, he rushes to the Tesman house to inform every one of the tragic events. This news devastates George and Thea, while Hedda seems somewhat joyful. Thea tells George that she kept all of Eilert's notes from their writing process, and George vows to work tirelessly until they can recreate the manuscript in full, allowing Eilert's memory and legacy to live on. Much to her chagrin, Judge Brack will entertain Hedda while George spends countless hours at his aunt's house with Thea, so Hedda retires to the back room and shoots herself, and the play ends.

\section{The Father of Realism} “Although possibly the performance was a trifle too realistic-little more so, I mean, than was strictly
compatible with the limitations of art."-A Doll's house

In the theatre world, Henrik Ibsen lives on as the father of realism. Many debate whether Ibsen was, in fact, the first to write a true realism play, regardless, Ibsen absolutely contributed greatly to realism's ultimate formation, and in the late nineteenth century, no one did it better. Many consider Hedda Gabler as one of Ibsen's most influential works, alongside such great works of theatre as A Doll's House and The Wild Duck, and exists as one of the most, if not the most, produced work of his some hundred-odd years later. Hedda Gabler not only deserves the 
classification of a well-written play, but a "well-made play" as well. By the time he completed Hedda in 1890, Ibsen had already established himself as an international success and his legacy of the well-made play proved well-written in the annals of theatrical history.

The roots of Realism theatre grow from the foundations of what became known as the "well-made play." Such plays adhered to a rather common and (to critics) pedestrian motif of writing where uninventive tropes and devices were used in place of profound characterization. A typical "well-made" structure involves artificial plots which clumsily build tension and conflict until all dilemmas are solved in a dramatic climax right before everything ends happily and well for the main characters. "The well-made play subscribes to writing of "technical skill, theatrical tricks, a basic structure, a formula" (Cardwell 876), which carries tropes and cliches familiar to the audiences of the nineteenth century. The progenitor of the well-made play, Eugène Scribe (1791-1861), throughout his catalogue of nearly four-hundred plays, did his best to remain formulaic and wrote of theatre: "I brought to life that which is real, but we do not see." By the time Ibsen started writing plays Scribe was closing in on the end of his life, and no doubt, Ibsen knew his work. While there is no expressed evidence of Ibsen taking direct influence from Scribe, the two men's dramatic philosophies aligned, and Scribe's plays thrived in the mid-nineteenth century, so Ibsen must have taken some inspiration from Scribe's writings. Though the format of the well-made play was shortly dismissed by critics as uninventive and lazy, the well-made play pleased audience members across Europe and the US, and was a staple of nineteenth-century playwriting.

Many people, artists and scholars alike, maintain that Ibsen did write plays that should be considered a part of the well-made play group, however, they contend Ibsen's plays are better described as "problem" plays. "Problem" plays, as defined by playwright George Bernard Shaw, 
pit their characters against a particular social or institutional convention that the playwright saw as problematic. This alongside the opinion that due to the nature of an overall progression in any given society, a problem play focusing on a certain issue or group of issues, will eventually render itself obsolete and "flat as ditch water" (Shaw 38) once (ideally) said society progresses enough to rid themselves of the problem. Regardless of how playwrights saw their own works, the truth comes down to the plays themselves and what one finds in its contents and construction. In fact, Shaw himself, despite many articles he wrote railing against the idea of the well-made play, wrote more than a few works later considered just that, a well-made play. Hedda Gabler is a good example of a play that has elements of both a problem play and a well-made play. One of the problems Ibsen dealt with in writing Hedda was something he wrote about in a number of plays-most notably eleven years prior to Hedda in A Doll's House, the validity of gender roles.

In the last century Ibsen has garnered the reputation of the first male feminist playwright, but Ibsen didn't see himself as a feminist, “I am not even quite clear as to just what this women's rights movement really is," Ibsen spoke at the 1898 Women's Rights League banquet, "To me it has seemed a problem of humanity in general" (Ledger). Nonetheless, the truth speaks for itself, and whether intentional or not, his play raised some important points and asked important questions concerning the perception and labeling of women. Ibsen had a number of works which call into question the role a person, wife and husband alike, should play within the household, and subsequently within a society, and Hedda exemplified those works.

Hedda herself is not a typical female figure of the late nineteenth century, and likewise, George not a typical male figure, and therein lies the gravity. The characters enable each other's differences and their differences give them their strength despite causing difficulties in their social dynamic. In A Doll's House, for example, Nora fights against the general perception of a 
woman's place in a marriage, and the men in her life did what they could to keep her in said place, particularly her husband, Torvald. George, however, does little to try to assign Hedda a "place" and when he does attempt to assert what little authority he can, the others either directly refute it, or make it the butt of a joke. A good example is the end of Act II as the men leave the Tesman's for the party at Brack's. Upon their exit Eilert gives Thea a time at which he plans to come back to escort her home, as the custom directed; George then says, "Don't expect me home early as that Hedda." as if he stood in charge of the schedules everyone keeps in the house. Hedda's response, however, "Stay as long as you — as you want," calls attention to the notion that she gives him permission to come home past his curfew, but in actuality she could not care less when ... or if he comes home. This is a moment of levity in the play because George acts somewhat unexpectedly, and Hedda responds in a way that would stand outside the custom for the time. In short, George's position as head of the house, or better thought of as his masculinity, not only gets called into question, but challenged directly, and by his own wife.

More importantly than Hedda breaking custom, George does not fight these challenges, and Hedda doesn't expect a fight. Though there are others who might question his masculinity, George does not seem concerned, as he has more important things to focus on . . like, for example, his research topics, his books, and his relationship with Hedda. Brack alludes to George's lack of authority when he says things about how George would make a poor politician, or simply in his shameless flirting with Hedda; and Eilert questions his validity as a husband, making it clear that Ibsen constructed George's personality deliberately, and purposely to comment on what does or should constitute a man. In the end George stands alone, wounded by the loss of so many close to him, but he stands, and with a drive, a purpose, and a will to make things right. Whether the audience agrees or disagrees with what Ibsen says about gender matters 
little, what matters most is that what he says gets noticed. Here Ibsen says that people and couples exist in the world who live outside of societal expectations and norms and ultimately represent the public at large and trying to keep people in boxes is an unjust oppression.

Any well made "well-made" protagonist has a character definitive arc that they follow, during which a change occurs within them. Usually, but not always, the character through whose eyes we see the story makes the biggest and brightest arc. One problem with such a play as Hedda, however, it lacks a consistent, singular point of view. Theatrical realism epitomizes the beauty of theatre as the audience is left to make their own judgments rather than have one forced upon them. Most people, then, probably assume the audience is meant to see the play through Hedda's eyes — and that assumption likely comes by way of her name being the title of the play. The audience, however, sees no more of Hedda's inner self than anyone else's. If they did, the most important events of the play would certainly have less of an impact. The audience would know all of Hedda's secrets from the start, of which there are many. Her pregnancy, the maliciousness of her jealousy, and they would likely anticipate Eilert's demise. Most importantly, though, seeing her on the edge of breaking, even at the beginning of the play, Hedda's suicide would not hit nearly as hard. Hedda Gabler comes at the peak of Ibsen's contribution to theatre, he perfected the art of realism, of voyeuristic theatre, and of dramatic social commentary. In his plays the audience does not always know exactly who to root for, and frankly, they do not need to know. Real life is subjective, everyone is a protagonist in someone's story or through their own point of view, and realism theatre exemplifies that. 


\section{The Birth of Hedda Gabler}

\section{“It must, must, must be a masterpiece!" -When We Dead Awaken}

Ibsen wrote Hedda Gabler during the summer and fall of 1879 in his cozy cabin in Munich, and the process went less than smoothly for him. He would sit for hours over his drafts, yet would constantly find reveries of fanciful summer holidays and gaiety with his family (a much different mood to that of the play) pulling his focus from the pages that lay before him. Finally, much to his relief, in the middle of November 1890 the work came to an end and he completed the play. Ibsen wrote in a letter to Count Prozor, the man who translated his works to French, "But it is a good thing, too, to have done with it. The constant intercourse with the fictitious personages was beginning to make me quite nervous" (Egan 247). One can hardly imagine Ibsen having the foresight to know the importance Hedda Gabler would hold more than a century later, but, no doubt, it would relieve him that his strenuous and frustrating work was not in vain.

During Ibsen's career theatre goers saw a stark division between those who enjoyed his work, and those who very much did not. Hedda Gabler opened in London's Vaudeville Theatre in the spring of 1891 and "emerged as a significant dramatic event, one that stirred up controversy, forced reexamination of Ibsen ..." (Gates 79). The run, meant to consist of just one week of matinees, ended up replacing the night bill show and lasted nearly two months; a success which Ibsen had not previously, or even since, seen on the West End. The reviews posted during the first week of performances exemplify such division which the theatrical community held, from critic to patron. On April $21^{\text {st }}$ an article in the Pall Mall Gazette titled "An Ibsen Success" claimed "if the Vaudeville is not fuller for the next four afternoons than it was yesterday, the public is a fool." Conversely, in the Illustrated London News on April $25^{\text {th }}$ Clement 
Scott compares watching the show to wandering a hospital morgue saying, "Down a little lower, still a few steps lower down, and we come to the dead-house. There, for the present, Ibsen has left us." One day later on the $26^{\text {th }}$, however, an unsigned notice in the Sunday Times read "Hedda Gabler at the Vaudeville this week must be accounted one of the most notable events in the history of the modern stage," and in conclusion the article states the show "is no more like a visit to the Morgue, as we have seen it described, than is Antony and Cleopatra ... or Hamlet with its wholesale slaughter." While Justin McCarthy writes in Black and White, "Hedda Gabler is the name, to my mind, of Ibsen's greatest play, and of the most interesting woman Ibsen has created," a notice in the Saturday Review once again references Shakespeare's Hamlet with which to describe Ibsen's body of work. "Things 'rank and gross in nature' alone have place in the mean and sordid philosophy of Ibsen." The Review notice goes on to say Hedda ranks among the best of Ibsen's work, but that is an admission made "without implying a word of commendation," and "it cannot be said that the works of Ibsen have the very faintest claim to be artistic. We see no ground on which his method is defensible."

Though Hedda Gabler, much like his previous works, initially received mixed reviews (Egan 232), it would grow to become one of the quintessential works of realistic theatre during the modern age. Most popular theatre in the mid-nineteenth century was bombastic and flowery, with heightened action and performance of one-dimensional characters and unoriginal motives; melodrama reigned supreme. The heroes represented absolute goodness and virtue, the cloaked villains, utter immorality and dishonor, flourishing music underscored the stereotypical action, and if the show did not end with the hero and the damsel, who he no doubt fantastically saved from sure peril, falling in love, winning over a crowd proved difficult. Theatre audiences were not accustomed to seeing realistic, representative characters, profoundly wrought and exposed, 
dealing with real, day-to-day issues; after all, real life is boring, right? Well, as it turns out, no. Despite Mark Twain not publishing his now famous "truth is stranger than fiction" quote for another seven years, Ibsen had great insight into the compelling nature of truth. "Realness" makes realistic theatre interesting, because the very situations and characters on stage resonate with intimate familiarity, for better or worse, to each person in the audience. Ibsen knew the true value of depicting real human characters and it comes through in brilliant detail with Hedda. In the same letter written to Count Prozor, Ibsen describes how he created Hedda Gabler with the specific intent of creating "human beings, human emotions, and human destinies." It would seem almost as though the idea of entertainment did not even come into consideration during the writing process, still the play entertains, because of realness.

Hedda stands apart from most other works insofar as Ibsen intentionally writes its main character, Hedda, wholly unlikable. Regardless how they felt about the play overall, critics and contemporaries would scald Hedda's character in their writings. They called her "a lunatic of the epileptic class" and a "white devil," one critic remarked that Hedda would "sell her soul and damn anyone else's for a little poetry," and George Bernard Shaw writes in his treatise, The Quintessence of Ibsenism, "with plenty of cleverness, energy, and personal fascination she remains mean, envious, insolent, cruel in protest against others' happiness, fiendish in her dislike of inartistic people and things, a bully in reaction from her own cowardice" (Shaw 126). Despite the bad taste with which Hedda stained the audience's theatrical palate — or perhaps unconsciously because of it, the play compelled, or at least interested people enough to run steadily across Europe and the US in 1891. The value of this play, however, relied not solely on the strength of its titular character, but all the characters' relationships. Part of what makes Ibsen's work successful is the masterful way he depicts realistic relationships on the stage. 
Hedda requires the support of each other character, else the play would fail to engage as well as it does, which is why "the ensemble that Ibsen creates is executed in a calculated, distinct, and masterful way" (Egan 219). The others must pick up her slack in temperament, or if nothing else, balance it out, in order to provide the best possible account of human interaction and behavior.

One of those characters, George Tesman, stands out among the husbands of the time as a prime example of Ibsen's skilled character development. Just as Hedda railed against the conventions of gender norms at the time-which indeed other Ibsen characters before her did, (e.g., Nora) so too did George. Perhaps because of distraction or simply willful ignorance, George failed to make a conscious impact on viewers, or at any rate enough to write about. Too bad Tesman has largely gone unnoticed during the play's lifetime, as he stands a proud testament to Ibsen's understanding of the humanity which he so finely crafts.

\section{First Impressions of George Tesman}

"When a man like myself, who is no longer quite young, has such a belief, or fancy, it makes an overwhelming impression." -The Lady From the Sea

I first encountered Hedda Gabler during my undergraduate tenure in a theatre history class; the place where early modern works tend to pile up. Museum pieces to many contemporary theatre goers. While plenty dates this play, it also contains an abundance of timeless material and it relates just as well to people in the twenty-first century as it did one hundred and fifty years ago; sadly, I missed that in my introductory reading. I enjoyed it, but did not have enough interest to delve deeply into the play, uncover anything special about the characters beyond their surface presentation or make any connections to current day life. A few 
years later I received the opportunity to play the role of George Tesman with Slipstream Theatre Initiative in Detroit. I gladly accepted, but went into the table read anticipating a rather mundane character within a museum-piece play. I saw George as utterly socially inept and mostly oblivious to his surroundings. I read him as spineless and meek, someone who would not engage in confrontation even if he knew how. He embodied superficiality and saw nothing more than that in others. What I eventually uncovered, however, surprised me with complexity and depth. This particular production was a modern adaptation, heavy in concept and light in traditionalism. Despite George's nineteenth-century composition, looking at him through a more modern lens broadened my understanding of him, and helped me to see that Ibsen's creation went far past the facade. With still more to learn, however, after the show closed lingering unanswered questions and uncertainties remained.

The beginning of my second year of graduate school at WVU presented me with my second major interaction with Hedda Gabler, as I once again played the role of George Tesman. This time, however, the production was much more traditional. Initially, I hoped that after having already performed the role under adaptive circumstances, that I would find a more traditional approach easier. I would discover, though, that the original style and period hold an entirely different set of implications which come with new and more complex questions for George, and I had a challenge in front of me. 


\section{Misunderstanding Hedda}

“Tis cold in here the blood runs icy through." -The Pretenders

This paper focuses on George Tesman, not Hedda, but I must cover a certain analysis of Hedda's character as it directly influences all of the other characters, especially George. Hedda Gabler is not a rigid, unpersonable, ice-queen. George loves Hedda because, unlike a lot of people, Hedda makes him feel comfortable and safe. People enjoy and seek her company; George says himself that, " . . there are a lot of people who would like to be in my shoes ..." Each and every person who wants to fill George's shoes cannot do so for no other reason than because of Hedda's looks - looks fade and are not the only quality suitors care about. Hedda's certainly not wealthy, nor does she have any significant station in society, especially since her father died. To support the story, not only must George love Hedda, but like her as well. To argue that something changed in Hedda after getting married and during her long and boring honeymoon would not necessarily go amiss; however, nothing in the text that suggests Hedda had undergone any significant changes. Additionally, she uses charm to ingratiate Thea and Eilert with great quickness after so many years apart. The characters in the play must find Hedda an extraordinarily likable person or they would have no motivation for a relationship with her.

Further support for this idea comes from George sincerely suspecting she is pregnant. Their relationship appears cold and stiff at first, but George does not seem reluctant about sharing anything with Hedda. Hedda, however, shares little: her feelings for George's family, her dislike of the house, and most notably the news of her pregnancy with George, to list a few. Ibsen uses Hedda's lack of willingness to open up to George as a red-flag, indicating to the audience the possibility of a duality in Hedda that opposes how others have made her appear. A malevolent force brews in Hedda despite her likable disposition, but for now, it exists only 
within. An affair would likely cause Hedda to keep her pregnancy a secret, but Ibsen presents no textual evidence to support that an affair occurred, let alone resulted in pregnancy. Despite the fact that Hedda becomes deeply enamored with Lovborg upon his return into her life, that emotion stems from a jealousy of Thea, not passion for Lovborg. Her motives stem from the need to feel power and control over something, or someone, not wanting to seduce people into sleeping with her. She would rather only deceive them into thinking she might sleep with them, and then not. Also, Hedda openly shares with others when she can use it to her advantage, and the subject of an affair would certainly make a strong weapon of manipulation in the correct circumstances. If Hedda acted outwardly manipulative or deceptive, or if George had any reason to believe Hedda unfaithful, finally confirming her pregnancy could cause a very different reaction from the joy he initially expresses.

All too often actors portray Hedda as cold and unfriendly and scholars and critics have described her as mean and unpleasant, "Inheriting from her father . . . his pride, coldness, as well as his imperious commanding attitude toward others ..." (Fahad). In truth, our production unfortunately suffered from a similarly cold depiction of Hedda. If Hedda is unlikable, then her relationship with everyone else in the play makes little sense and the foundation of her dramatic action crumbles; everyone likes Hedda.

Aunt Juli likes Hedda well enough to revel in the fact George married her, in fact she calls her "the girl of [his] dreams"' (Turner 9). Juli constantly mentions Hedda's beauty and wonder, and how fortune allowed George to marry her, particularly because she attracts so many suitors in town. The play makes Judge Brack's infatuation with Hedda clear early on. He spends a great deal of his time at the Tesman's, and generally does not go to see George.

BRACK: I take it your husband isn't home yet? 
HEDDA: [Locks the pistols away in a drawer of the writing table.] No.

The moment he finished eating he was off. I suppose to his dear aunties.

He wasn't expecting you so early.

BRACK: Why didn't I think of that? Stupid of me.

HEDDA: [Turns her head and looks at him.] Why, stupid?

BRACK: I'd have come a little sooner. (Turner 34)

Brack, a much older, well-off man holds respect in the community and sits in a position of distinction as a judge. One would assume that finding companionship would come easily for him, therefore Hedda must have a particular draw that has captivated him. As soon as Lovborg enters the picture he says himself he still holds a burning flame for Hedda, and it does not take long for him to start reminiscing about their romance and pine for Hedda's approval, despite the years apart. "I told you things about me that no one else knew" (Turner 52). It takes an awful lot of trust to expose your deepest thoughts and secrets to someone, a person who receives such trust must surely be welcoming and affable. In fact, over the course of a short visit, Hedda riles him with such passion he falls off the wagon in the sitting room, right in front of everyone. Thea, despite insisting that Hedda frightened her because Hedda used to bully her in school, spends no more than ten minutes with her before divulging a lot of personal information. Thea even says to her, "You're so kind. I'm not used to people being so nice to me" (Turner 20). Hedda's personality and approachability disarms Thea, something that a mean, callous person could not effectively execute. George, without question, loves Hedda, whether blindly so or not, he sees her as a beacon of beauty and hope. 


\section{Textual Analysis and Observations: Where are the Parents?}

\section{"No parents hand had kindled it." Brand}

The absence of parents winds throughout the play, both figuratively and literally. Aunt Juli is the only one who mentions George's father, Joachim, and she does so only three times and only in reference to his absence. Aside from the fact that he long since passed, no one explains exactly what happened to Joachim, or when. There are, however, similarities drawn between George and his father one more than one occasion. Early in Act I Juli refers to George as "my dear Joachim's own flesh and blood" (Turner 5), and shortly after says, "your father was the same way. Like father like son" (9). This indicates that during George's father's life, the two had a strong connection with each other, and that his role as a father ended abruptly and early. Similar to the theft that occurs when Hedda dies, taking their unborn child with her. While Juli suggests a positive connection between George and his father, she also implies that Joachim passed in George's early years. The line "wouldn't it be wonderful if Joachim could come from his grave and see what's become of his little son" (Turner 3), alludes to the fact that the pet name originated when George was little, and therefore likely young the last time he saw his father. Subsequently, with the help of Berte, Juli and Rina raised George since his father's passing and at times refer to him as "little" George indicating that he must have been young when his aunts took charge of him. Growing up without a father proves difficult for most children, and could have caused some of George's social ineptitudes. Even more likely, the absence of a typical nineteenth century male figure in his formative years has led to George developing into the atypical man in adulthood. Furthermore, as typical of the time, a young woman's father would "give" her to a man when he wed her, essentially becoming the woman's male figure who was 
then charged with providing for and watching over her. Without getting too close to an Oedipal line, Hedda lost her parents and it now falls on George to provide the role of caretaker; however, she does not want this for herself, and she feels as if she has fallen into someone else's hands unwillingly.

Hedda's father is also passingly mentioned, but beyond the fact that he was a respected general, he remains a mystery to the audience ... and perhaps to Hedda as well. She does not mention her father once except for her very last line of Act I, “[Her eyes cold.] General Gabler's pistols. [She goes into the rear room and disappears]" (Turner 32). She calls him General Gabler, the title used by Juli and Eilert, and no doubt anyone else in a subordinate position to him, but a title that one would not expect a daughter to use for her father, a potentially single father, in fact. She delivers the line with a cold stare no less, and then immediately disappears from the stage-which coincidentally, is the one and only time the audience sees Hedda make an exit aside from when she enters the backroom to shoot herself. The third and final time her father is mentioned comes in Act II when Eilert reminisces about his and Hedda's brief tryst. He says, "the general sat by the window . . His back was always turned towards us . . " He does not say anything along the lines of when his back was turned, or as he turned his back, he says always as if to indicate that there was never a time when Hedda's father did pay notice to notice her. The General's emotional connection with his daughter is absent just like his mental perception of his daughter, and now absent in bodily existence. Yet despite his rare appearances in the script, his portrait looms over the stage, ever a reminder of something Hedda never had.

For both George and Hedda we have a mention of a hereditary connection to the paternal side, but no references, let alone specifics, about anyone's mother. George remarks how Juli raised him like a mother and a father, so it would seem he had no relationship at all with his 
actual mother. Hedda, however, Hedda will soon become a mother, and George a father; again, something not directly said, only implied. The implication here is a bit of foreshadowing. The mothers are mysteriously absent from the children's lives, who are then raised by single fathers. Perhaps calling that foreshadowing lands a bit too on the nose ... or perhaps not, regardless, it could not have been an accident on Ibsen's part. The thought of both he and Hedda growing-up without meaningful relationships with their parents must weigh on George in the face of his potential fatherhood. In any case the duty of responsibility of a child's life rests heavily on new parents, and much of how they raise their children is based on what they experienced with their own parents during childhood. With absent parents, a void exists in one's understanding of how things ought to be, what works and what doesn't, and plainly, how their parents made them feel.

Thea and Eilert can factor into the theme of parental absence as well. Thea says she has no children of her own, but she married a man who has children from a previous marriage, thus becoming the kids' stepmother. Not long after she reveals that she plans on leaving her husband, essentially removing the mother from her stepchildren's lives for a second time. In Act III when Eilert explains to Hedda his rendition of how he lost his manuscript, he refers to it as his and Thea's "child." He then goes on to say that losing a child is worse than killing a child, and laments not knowing "where he is or whose hands he's fallen into" (Turner 79). A fate worse than death, according to Eilert: a child separated from their parents and left in the hands of someone else. Just as George was in his youth, and similar to how Hedda gets left for George when her father has died.

As a bit of speculation, I would like to mention that Ibsen himself had five siblings, all born into affluent society, which can lead to not only a thin division of attention, but also spending more time around hired care-takers than the parents. Furthermore, in Henrik's 
formative years his father lost a tremendous amount of his fortune during difficult economic times. Despite this, however, the family remained members of high society. Having no money while trying to keep up appearances would certainly put added stress on Henrik's parents, perhaps causing strain on their relationship with their children. While Ibsen has been forthcoming with the fact that he based a number of his characters on his family members, he never mentioned anything about a specific influence for the Tesman's, and both of his parents lived well into his adulthood.

\section{The Rubber Band Theory}

\section{“I go only to return again.”-Catiline}

The play begins with George's Aunt Juli talking with her former housekeeper, Berte, now employed by George and Hedda. Juli spends much of her time gushing over George, the house, and even Hedda. Aside from exposition, Juli's praise serves as a foundation for George and Hedda's relationship to each other. Juli paints a picture, one of a happy new couple living in their dream home with optimistic career possibilities and perhaps an addition to the family. The audience then uses this picture for reference as the events of the play unfold and uncover the truth of their lives together. Ibsen reveals a part of real life that focuses on crises which were "largely misunderstood and unappreciated during his lifetime" (Means), and rarely exhibited in plays of the nineteenth century, thus leading many audience members and critics to believe these truths that Ibsen writes are illegitimate, and not really truths at all. Ultimately the play presents to us with a struggle between expectations and reality. The audience follows along and becomes a 
part of this fight between expectation and events, plunging them deeper into the investment of pity and fear of Aristotelian philosophy.

George strives for a life that matches Juli's perception, while Hedda dreads such a prospect and begins to move away. We can think of the two connected to each other by a metaphorical rubber band centering in the middle of the world that's presented. The other characters appear in between George and Hedda, separating them. The more characters that appear in the center of the rubber band's loop, the less slack George and Hedda's relationship has; as one moves in one direction it gets harder and harder to continue without the other following, pulling them in the opposite direction, relatively, in their relationship to the characters. As Hedda moves away from George he is pulled toward the others in the middle, but If one character has enough support to provide adequate resistance, the rubber band will snap, disconnecting the couple, leaving one near the group while the other's momentum carries them away. George will wind up closer to the group in the middle, mostly because of Hedda moving away from him. Initially, George has Juli as a support post, while Hedda, begrudgingly, has Brack. As Thea and Lovborg come back into the couple's lives the old friends gravitate towards George and Hedda respectively, maintaining the balance in support. The balance exists until Lovborg leaves Hedda's side ... or anyone's for that matter. At that point the supporters are unbalanced which holds George in place, while Hedda, fighting against the tension but unable to resist the band's recoil with what little support she has left in Brack, stretches the band beyond its limits carrying her into the unknown. 


\section{Perceptions - Misdirection and Subtext: The Great Filter}

\section{“Deep-seated instincts of decency which restrain us within proper bounds." -Pillars of Society}

Ibsen does a good job of masking George's quirks and insecurities ... almost too good. It takes a long, hard look at him to notice the depth of his character, especially amid the other characters who appear more interesting on the surface. While this can cloud George's robustness, it does serve him, and it serves the play by making the character more human. Human beings do not often consciously show their hands when it comes to what they have hidden deep down inside; people have a natural "filter" that uses our thoughts to decide what we should and should not say. Theatre often seems to lack this filter, much of theatrical drama exists in extreme circumstances where the characters commonly bypass their filters in order to move the plot, create drama, etc. Naturally, this lack of a filter can help the pacing of the show as there are only a couple of hours to unwrap the whole story and tie things back up again, but it can also make some characters feel less than authentic, or at any rate make their actions and motivations feel contrived. George has this societal filter. It is a defining feature of his as it informs and separates him from the group. George, seen on the same equal and filtered ground as the rest of the characters, seems flat and unable to provoke action, and therefore he appears inconsequential to the bulk of the plot. This filter, however, is the reason that the audience is, perhaps subconsciously, drawn to George in a way that allows for a better connection through identification. George's filter can be understood by those watching him the way people understand each other on an intrinsic level. Even if they are not able to describe exactly why, audiences will sense a familiarity in George's personality. 


\section{Character is in the Eye of the Beholder}

\section{"You may call in the aid of competent men, at your own choice, to decide with you in these affairs." -Emperor and Galilean}

The audience finds themselves seeing George from different angles and perspectives and are presented varying accounts of his character by a number of characters thus creating a mystery of his character. The very opening scene of the play has Aunt Juli and Berte speaking very highly of George, talking about his new title of "Professor" and how smart and kind he is. "There's no limit to what he might become," says Berte, "He's that smart" (Turner 3). When George enters for the first time shortly thereafter, his demeanor and overall attitude substantiate the women's conversation. Early on Juli and Berte lead the audience into thinking George is a real stand-up kind of guy. It is not long, though, before Hedda starts to cast doubt about George's overall worth, which doesn't entirely discredit the opening conversation, but piques an interest by calling attention to differing perceptions of him. The conversation between Hedda and Judge Brack in Act II reinforces this dual perception of George as he speaks well of George- - even if he finds it difficult to take him seriously. At the same time, Hedda demeans George's worth, calling him boring and single-minded, and questioning why she ever married him in the first place (Turner 36).

Later in the act, Eilert makes a remark that elevates George's mystique; Lovborg says, "I only want to defeat you in the eyes of the world" (Turner 48), when George asks if he will compete with him for the professor appointment. That statement speaks magnitudes, the world has a lot of eyes. This certainly gives the audience a glimpse of Eilert's character, but the remark also presents the audience with an insight into the two men's previous relationship. It's known George and Eilert were at one time close friends, it is also known that some time ago Eilert 
became disgraced in society, and most importantly, that a fair amount of competition takes place between the two men. George expresses his jealousy of Lovborg on a number of occasions and Juli goes as far as to call Eilert one of George's "enemies" and his "most dangerous rival" (Turner 8). When George learns that his potential professorship has been degraded from a sure-thing to a competition, it is the knowledge that he must compete specifically with Eilert that drives him to distemper. With those things in mind, Eilert's remark about defeating George in the eyes of the world then opens the audience to the possibility that George had something to do with Eilert's dishonorable standing in the community. Later in the same scene George does apply some pressure to Eilert, goading him to come along to Brack's party despite Eilert's refusals. It could just be George's happiness and excitement to see an old friend again combined with learning that he won't need to compete for the position after all. The audience sees multiple perspectives of George to raise more questions than answers regarding his true character. Ibsen then leaves the audience to decide, he does not tell them through George's own admission, or confession in declamatory or clandestine conversations. Audience subjectivity is a keystone in theatrical realism, and something Ibsen excelled in. The prominent critic, Clemens Peterson, said of Ibsen in an August 1882 article:

Ibsen ... stops short at the suggestion, the explanation, the instruction.

He may startle the reader, but he does not force him into a decision. He may warn all passersby that the house is falling, but he does not tear it down himself. (Egan 58)

Peppered throughout the earlier scenes of the play we get others' interpretations of George, while George himself utilizes the filter and maintains his defenses. During the climax of the play, in Act IV, when George drops that filter revealing a different side of himself after he 
learns Hedda burned the manuscript, he grows briefly, but increasingly, angry, he makes demands of her, and even initiates confrontation. This moment is confirmation that George has more depth than he allows others to see; the questionable shadow cast on him by the other characters suddenly seems validated, and all at once brought to mind. For the first time George's filter falls away and again Ibsen leaves the audience to make a decision about George. George's facade of a lack of depth actually contributes to the depth that is hidden, because of real life. Humans are three-dimensional characters simultaneously good and bad, serious and giddy, liked and disliked, and judgment is left in the eye of the beholder.

\section{George's Selflessness}

\section{“Will you never be tired of making sacrifices for me?" -Hedda Gabler}

In further examination of George's reputation as a lesser character Ibsen pulled out all the stops with subtext and intricacies. George exudes a gentleness which overpowers his other qualities at times. Pleasing Hedda is George's first priority by doing whatever he can to give her the best life possible and the life she wants. That in and of itself is not a negative quality, but when comparing his treatment of Hedda against her treatment of him, it becomes clear that George doesn't share equal footing in their relationship, thus giving his character the negative quality of submitting to Hedda's beck and call despite her not wanting to make compromises for him. In Act I when the couple learns that George's position at the university has contenders and they may end up having less income, Hedda responds with simply, "I don't intend any of this to alter my plans" (Turner 31). Unwilling to make small sacrifices in her social appearance so that they may live more comfortably, George (willingly) takes on the expectation of doing whatever 
he needs to so Hedda will not need to make those sacrifices. The snide follow-up Brack offers, "Well, that's your business" (31), darkly, yet comically, indicates his awareness of who rules the roost in the Tesman household. In fact they only live in the house they are in because Hedda tells Brack, "I just mentioned in passing ... that I'd love to live in this house" (41), despite actually liking the house at all. Additionally, the expensive honeymoon they took happened because Hedda wanted so badly to travel; likely George thought he was doing Hedda a favor by having a six-month honeymoon abroad. This willingness to do whatever others ask of him is apparent from the beginning through to the end of the play. In Act IV when George stands up for himself, he does so frantically and it stands out as a definitive moment of contrast. In his first conversation with Juli she questions him on a number of things: why he had to go away for so long and his dedication to his research, all of which George meets with hesitant answers regarding the wishes and welfare of Hedda. "Hedda had to have all her luggage," as an excuse to why he could not give his aunt a ride home from the pier, and "Hedda simply had to travel," "I'm especially glad for Hedda's sake we got this house," "Hedda's the loveliest thing of all."

Now, it is no surprise that a newly married man would find his wife infinitely lovely and want to dote on her, but George never mentions doing anything for himself. He even starts to feel bad when Juli tells him she took out a mortgage to help him with the house, "always sacrificing yourself for my sake," he says to Juli unironically—as he makes whatever sacrifices he can for Hedda. George has not completely ignored himself, though, as he has obtained a doctorate, but he was not the only person who stood to benefit from his degree and education. The primary reason for his study and research are his aspirations of becoming a professor so he can get a well-paying and well-respected job. Later, after Brack tells him he might need to compete for the position, he explicitly states that in his application for the appointment one of his motivating 
factors was his marriage to Hedda, "it was on the strength of the appointment that Hedda and I got married" (Turner 29). Later in that scene Hedda laments George possibly getting beat out for the position, not with compassion or sympathy for George, but with disappointment she can no longer afford a liveried footman and a horse. George has always been a scholarly man, but the text would indicate that he strove for the job-and possibly the doctorate, so he could provide Hedda with the "society" she so badly wanted.

\section{The Butt of the Joke}

"Oh he has teased me so long."-Little Eyolf

A number of people in the play don't take George as seriously as he deserves concerning a variety of subjects. In Act II when Eilert tells George he has decided not to compete for the professorship, he does it in such a way as to seem like if Eilert did not concede, George would have no chance of winning. Furthermore, he talks about defeating George in the eyes of the world with his new book, with no knowledge of anything George has recently written. Later, when Hedda and Eilert chat quietly with each other, Eilert expresses that he thinks it is a joke that George and Hedda married, "to George Tesman of all people ... George Tesman." He laments having to call her Mrs. Tesman from now on, he remarks, bitterly, that of all people she married George, and asks her why she chose to "throw herself away like that." Earlier in that same act, Hedda muses to Brack that perhaps George might make a career in politics, to which Brack immediately scoffs, citing failure as a likely outcome. The number of times Hedda demeans George and his choices are many, not to mention she calls his professorship "wretched" and will not even "waste [her] time worrying about that" (Turner 43). The very thing George has 
worked so long to achieve, the career that he will use to provide for Hedda and all her liveried footman, horses, and pianos, Hedda essentially sees as a pointless use of time. The way in which people are seen by others can have an effect on how people see themselves as well. Surely George knows he is a capable person, but doubt will always linger; It shows through in his deep jealousy of Eilert, his need to constantly keep up with happenings in his field, and internal things like his insisting Berte, the woman who helped raise him, come help him in his new home. Sure, he is a quintessential nerd who enjoys a good book and the simple pleasures of filing and indexing, but it goes far beyond that; the other characters view him as incapable, despite having shown no evidence to support this. The text has zero indications George has ever failed at anything. He is a writer who has earned a doctorate, secured final consideration for a professorship position, obtained the exact house that he hoped to purchase-despite the fact it was not even on sale when he set his sights on it, and married the woman of his dreams even though she does not truly love him. None of those things are easy to achieve, and all that occurred just what within the last year or less; he must have seen success as a younger man in order to set himself up for the aforementioned achievements. Moreover, at the end of the play he begins the process of recreating what he describes as "one of the most remarkable books ever written" (Turner 66), and doing so for the sake of someone else's name. George may not be a social butterfly or a someone rich and famous, but he achieves what he sets his mind on, a winner plain and simple; yet no one else, with the exception of his aunt, treats him as such.

As a result, of others not believing in him, and immense focus on his success, George must suffer from a certain degree of social anxiety and a lack of social skill development, which is something typically seen among the stereotypical "nerdy" group of people, or "geeks." Geeks defined by specific cultural passions, passions which do not generally top the list of people's 
interest. Interests such as his research, and the topic of his new book, the domestic industry of Brabant in the middle ages. Research by itself might not garner such criticism from Hedda, but George's research is niche to the extreme. Likely most people aside from historians are those in the Benelux region in Europe would not have heard of Brabant or know what it is, let alone care about the state of its economy more than seven-hundred years earlier. Those who feel inadequate in social situations tend to fixate further on specific topics as a way to cope with an insecurity that stems from the way others perceive them due to their interest in those very topics. At the top of Act II George enters with a plenteous amount of books, to which Hedda (unsurprisingly) scoffs; "One must keep abreast of what other people are writing," he defends. The text he reads and the pages he writes are something within his control, they are something to hold onto for George, who feels like little else within his control. His profession relies on those things, yes, but they also serve as an escape, a place where George can be taken seriously by a community; and one of the few, if not the only, place (certainly domestically) in which he has at least a modicum of authority. He collects a lot of books, a whole room's worth, and he spends a fair amount of time with his books and his research, as Hedda so woefully points out to Brack in Act II. Juli even makes remarks concerning his research, and though she takes pride in his achievements overall, she expresses surprise at his doctorate, and lightly chides him concerning his affinity for research.

George also has an overwhelmingly close relationship with his aunts. Which, again, is normally nothing that others would criticize, but among all of the other characters in the play George alone exhibits this kind of familial relationship-in fact the play suggests quite the opposite, that the other characters push themselves away from families. It sets him apart from the others, and more, it sets him up as the butt of jokes and distraction. Hedda does not care much 
for Juli, she passes out sarcastic comments such as, "I'll try to get over my disappointment," after George tells her Juli cannot visit, and, "these eternal aunts." Hedda even refuses to use the informal name of Juli when addressing her, despite knowing that it would please both Juli and George. When George mentions the seriousness of Rina's sickness, the only consolation Hedda offers is that "she is always very ill." She tells Brack as much when she smirkingly confesses she knew the hat which she called ugly in the first scene belonged to Juli, and it would make her happy to never have to visit with Juli again. Brack then responds with a snide "Shame on you, Mrs. Hedda! How could you do such a thing to that sweet old lady?" clearly droll and sarcastic. Perhaps this is just a way for Brack to ingratiate himself with Hedda, regardless, it establishes that it is not exactly in-fashion for George to have such a close relationship with his aging aunts. George's special interests and his relationship with his aunts collide when Juli gives him an old pair of his slippers which Rina specially embroidered. "Oh them," Hedda remarks unenthusi-astically, while refusing to even look at them, claiming, "they've nothing to do with me, do they?" They are old and used, but they are something that makes George happy; therefore, Hedda considers them a trifle, the punch-line to a joke at George's expense.

\section{The Heart vs. the Head}

“Who has filled my heart with bitterness?”-Lady Inger of Oestraat

George is not a daft person. He spends much of his time reading, both historical and current affairs, he recently received a research grant and obtained his doctorate overseas, and has, essentially, secured a professorship position. Intelligence and wisdom are different qualities, book-smarts and street-smarts for example, but just because someone lacks aptitude in the ways 
of engaging with others on specific topics - or even with people in general, does not mean they are oblivious to their surroundings.

The biggest question to ask about George concerns whether or not George suspects Hedda's pregnancy but he is simply too awkward to ask directly. His remarks early in the play would suggest either suspicion or such aloofness that he genuinely thinks "she looks healthy and filled out." He asks everyone that comes into the house how they think Hedda looks, fishing for some response he can catalog in his brain. Regardless of whether his analytical brain will allow him to truly recognize she is pregnant, his heart wants badly to believe so. In Act III when finally "revealed" that Hedda is pregnant her disclosure comes across as vague to say the least. There is direct mention of a baby or a pregnancy, only an allusion to their relationship as a family unit, and a mention of asking Julia, "Maybe it's time you did know Tesman, now that-. No I won't say it. Ask your Auntie Juli” (Turner 85). Hedda delivers the news ambiguously, but George knows exactly what she means; there are two reasons for this and they are not necessarily mutually exclusive. George either has enough smarts to suss out the obscure language - impressive as it may sound, or he has hoped and believed for some time, and just waited for any bit of confirmation regardless of how small, because the thought of the interaction that would take place if he was incorrect would terrify him. Both live within the scope of George's character, which circumstance is more responsible does not matter, what does matter, is that in this moment he reveals a bit more of himself, and it's the first major step in George's transformation.

More revelations follow in the scene, and shortly after the confirmation of pregnancy he realizes how unhappy the prospect of parenthood makes Hedda, and his hope for a loving family starts to fall down around him. Not because of unawareness or daftness, he is just flawed by 
believing only what he can confirm and hoping against hope. The last few moments in that scene are among the best in the play; the ups and downs George experiences and the final exchange between the two: "I wonder if young wives often have such love for their husbands." "Why don't you ask your Auntie Julie," "I will, as soon as I get the chance." Most interpretations of this scene make George seem giddy and happy because he thinks Hedda really, truly loves him now. That is decidedly not the case here. George may have some love-induced myopathy, but not stupidity; as much as love can close one's eyes, when reality smacks them in the face, their eyes open wide. In this moment George's fantasy starts to dwindle as he realizes things will not turn out quite as he had hoped.

\section{Oblivious or Oh, Blivious}

"Do you think I am not quite aware of that? My object is precisely not to get it." -An Enemy of the People

At times other characters speak as if George cannot hear them, despite him being within earshot of the conversation. They truly believe that George is simply oblivious to his surround-ings. Hedda remarks a number of times during her covert flirting with Lovborg in Act II that George will pay them no mind, and he will not notice the serious conversation the two are having. He does, though, and while what his heart doesn't want to believe may obscure his perception, or his awkwardness will not allow him to properly respond, obscurity does not equate to blindness. George says something to Hedda during that scene that does not initially stick out but upon reflection his words ache. "I like waiting on you Hedda," he says in response to Hedda questioning why he returns to the room while Hedda "keep[s] Mr. Lovborg company." Either George tries coming up with a frivolous excuse to mask the true reason he came back, in a moment of anxious suspicion, he tries to softly convey to both Hedda and Lovborg that he loves 
her. In fact, George is so distracted, one way or the other, he pours a second glass of champagne despite knowing full-well Lovborg no longer drinks. His quick thinking allows him to come up with an excuse, but the context makes it clear the pour was not intentional. "Ah. —But Mrs. Elvsted will be here shortly." The "ah." followed by the dash lets an actor know something specific must happen on this line. Delving deeper, the rest of the interaction contains more tactics George uses to confirm what he witnesses. "You didn't remember her?" as if indicating he knows she is distracted, and then following with an attempt at reminiscing of their time together on their honeymoon, "Down near Brenner Pass ... what fun.” Top it off with, telling Eilert, "I wish you could've been there with us Eilert," in a pointed way that almost suggests a shaming tone.

Much talking underneath one's breath happens in the Tesman household as well. It could be said that Ibsen uses this simply as a dramatic storytelling device, but Ibsen executes his writing too artfully and uses subtext and character too well for him to use something for "simply" anything. A good example: in Act II after George tells Hedda Juli will not visit— to which Hedda shows no disappointment, she says, "Ah, these eternal aunts." A reference to how close of a relationship George has with them and how they are always present, the fact that Juli wants to come and visit every day, and possibly, even a jab at the fact that Rina is still alive despite being "always quite ill."

\section{The Question of Love}

"How can true love reach its goal when riches leaden weight subdues the soul. How can true love
speed when life's a battle to the death with need." -Love's Comedy

Does George truly love Hedda? The question of whether Hedda loves George gets answered pretty early on in the play, when Hedda says as much herself: "I never use sticky, silly 
words like love," "why did I ever marry him in the first place?" Ibsen makes it clear to the audience by Act II that the story is one of unrequited love. A question, however, of George's romantic authenticity comes up; whether he actually, truly loves Hedda, or he sees her as more of a trophy than a lifelong companion. Speculation is difficult, and one's opinion could change depending on the character's lens which they choose to view the story; in fact, the idea that George sees Hedda as a prize was brought to my attention by someone who played the role of Hedda opposite me during my first endeavor as Tesman. Coming from Hedda's perspective it makes perfect sense to believe that George is not truly in love with her; it helps with her motivation, it helps her keep some semblance of a conscience, and can even help propel her to her final moments in the last scene when she sees George working so closely with Thea. This question is exactly what makes Ibsen such a craftsman and this play so well done, though, Hedda not thinking George loves her is perfectly valid, but George does love her, and we have proof.

Firstly, according to Hedda, George spent most of his time on their honeymoon neglecting her, preferring to look more toward his research than his new bride, "rummaging around in musty old libraries" while she sat "bored to tears." Earlier George confirms that he spent a good amount of time working on his new book, exactly how much time we do not know, but he never mentions, or even alludes to, Hedda's frustration with this. We do know, however, that Hedda is an unreliable character within the literary context of the play. She flat out lies a number of times, and also takes great pleasure in her duplicity and manipulativeness. The question of George's reliability, on the other hand, never comes into question. George Tesman never tells so much as a half-truth, he is, in fact, forthcoming with everything he knows, partic-ularly to Hedda, and of all the main characters of the play he is the only one who actively tries to conceal something from someone. If the audience gleans anything from Hedda talking 
down about George it supports the malignity of her character, not the shortcomings of his. In fact, when pressed by Juli to divulge information about the trip, (no doubt in order to get some information on the pregnancy) he mentions that despite the difficulties of the trip, he did it because "Hedda simply had to travel." An expression of his love. As to the matter of conducting his research during the honeymoon, the audience has no reason to believe that he did it entirely selfishly. When Juli comments on how much it must have cost to take the trip, George agrees, but then says that the research grant he got went a long way to cover the expenses. To go on a trip for the benefit of someone else, while using money awarded to him because of his work and achievements, with expectations of more work to follow, does not allude to selfishness.

Concerning the appearances of their marriage, George treats Hedda like a gentleman, not a simple object of beauty that one would associate with a typical trophy-wife. He does not have the money or prestige for that, and he does not take her around town showing her off in any way. In fact, Hedda expresses concern with "enter[ing] society," not George, George simply agreed (yet again) to what Hedda wanted. Additionally, he uses the word "select" when talking about their potential circle of friends, which indicates that he is not concerned with people seeing him and Hedda together. George would live perfectly happily making "do with each other's company." While he does ask people's opinion of her looks, as was covered, he uses that as a device merely to suss out whether or not she is pregnant.

Numerous times early on in the play George mentions how beautiful and "healthy" Hedda looks lately, asking others to confirm his observations. He suspects her pregnancy, but, as discussed, his inability to pick up on social cues makes it hard for him to determine, particularly when Hedda actively tries to keep it a secret. Pregnancy in a relationship all too often provides false hope for those who find themselves in an unrequited love. The misconception that a baby 
could save a relationship is pervasive, if mostly inaccurate and as a result, destructive, especially in a time when families meant more than just a benefit for the couple, but a part of proper society as well. Hedda being pregnant gives George hope that a child will invigorate Hedda's love for him and bring their marriage to the level to which he desires. At the beginning of Act IV when the confirmation finally comes, he shoots over the moon with joy, only to be brought crashing down when Hedda will not-and can not, share his enthusiasm. George hurts profoundly in this moment, and this is the first time the audience sees him with a bit of a bite in his words. This marks the biggest turning point for George in the play, he begins his transformation here because the realization explodes like an atom bomb to his heart. Through it, he tries to maintain a spirited facade, perhaps attempting to drown out the hurt by focusing on Juli's reaction and how happy it will make her; but the facade could stem from spite, trying to make Hedda feel guilty for not wanting a child. Regardless, he now knows Hedda does not love him like he thought she did, but he just does not want to believe it; he appears delusional, but love often has that effect on people.

In Act III after George returns home from Brack's party with Eilert's manuscript he receives a letter from Juli stating that Rina's health has taken a turn for the worse and she rests on the brink of death. If he wants to see her one last time he must make haste, and immediately George asks Hedda to come along, "Hedda, dearest, can't I prevail on you to come along? It would mean a lot" (Turner 68). She declines with a flimsy excuse how she cannot bear death and "ugliness" and he says, of course, he understands. That was not disingenuous, though, when he said he understood—of course Hedda would not want to be around someone dying, few would, and him understanding her position proves the point further. Plainly, when George learned that one of the women who raised him is dying, straight away he asks his wife to come along to support him by his side, and that it would mean a lot. He wants Hedda there because she 
comforts him, and she means nearly as much to him as his aunts. When Hedda refuses to go George does not take note of how selfish and inappropriate it is, it makes perfect sense to him, it has to, because how could Hedda be anything but perfect?

Using George's social ineptitude in the context of the validity of his love, helps support the argument for actual love. Love is difficult to define, as is being in love, but when it happens to them, people know. Ask ten people to define love and one is likely to receive ten different answers; however, when asked about being in love, generally, there are only two, very distinct, answers to whether or not someone is experiencing love. it when they feel it. Love exists as an intangible feeling, undefinable, and uncontrollable, but recognizable nonetheless. What some may call "just a case of puppy love," feels no less deep and honest to the puppy. George may not have the social development to understand the process of love according to the same standards as others, particularly with the divergent gender roles depicted, but he is in love because he feels like he is in love. The heart wants what the heart wants, sometimes the brain tries to douse the fire, but that does not make the flames in one's chest any less hot. Five years later he may realize that he was merely infatuated with Hedda and not truly in love with her because she did not share that love with him; at this moment in time, however, it is authentic.

\section{The "Other"}

\section{"You found it troublesome to be a mother ... thus you have become a stranger to him" -Ghosts}

Something else to consider when discussing the literary roles these characters play are the categories they should fit. From the very opening scene the play sets up George as someone with an established presence in this world. Not only someone who everyone else in the play is 
familiar with, but also as a pillar of consistency and dependency. "Ah yes, you always did like filing and indexing" Juli says in the first scene, that along with statements like, "I've never known George to be ..." and Thea claiming, "You are the only ones I could turn to," make it clear people rely on George and have for some time. George may not fit into social groups the same way, but he undeniably belongs. Hedda, on the other hand, exhibits capriciousness and impulsivity, and someone who does not stand out as a pillar of reliability. She constantly goes to odds with everyone and everything in the world, others speak of her as if she looks better while admired from afar, she is not a real member of the community, and she does not seem to "belong" there; she is an outsider. While all of the characters somehow share a relationship that extends outside of the context of the plot, George's relationship with each of them stands more stable and concrete as proof that Ibsen wrote Hedda as "the other" in this story. The Other is an archetypal character who others perceive as not belonging to the group and that they are different in some fundamental way. The group sees itself as the norm and judges those who do not meet that norm (that is, those who are different) as the Other (Melani). Labelled as outsiders, they purposefully do things differently from how the rest of the characters do things, and they are a source of wonder and suspense for a story. In certain cases these outsiders can turn out as unlikely heroes or saviors, but this is not that kind of story. In this instance the other is the source of grief, the plague cast down upon the rest of the characters, the source of the conflict; In so many words, from Act I Hedda establishes herself as an antagonist.

As an antagonist that does not necessarily preclude someone from acting as the protagonist, and while Hedda certainly antagonizes everyone else in the story, she also does so to herself. Likewise, a story could have two protagonists. Take Samuel Beckett's Waiting for Godot (1953) as an example: between Estragon and Vladimir one would have a hard time choosing just 
one as the focal character. They both share equal weight in the unfolding of the story, they both begin and end in the same place, and they both strive for the same thing. In the case of Hedda Gabler, though, both Hedda and George clearly want different things, so if they cannot share the duty, they must split it, and in an uneven split one must better suit the role than the other ... one better than the other.

\section{Doing vs. Undoing}

\section{"A thousand words leave not the same deep impression as does a single deed."-Henrik Ibsen}

While likable is a vague description, it makes it easier to define when drawing a distinction between likable and fascinating. Fascinating insofar as the audience's fascination while watching the character in question, and perhaps enjoying what they see in that moment, while simultaneously not liking what they see. Catastrophe draws attention, as human beings we cannot help but to rubberneck curiously at an accident on the street or glue ourselves to a news report covering a natural or social disaster. It is the very principle that guides Aristotle's definition of tragedy evoking pity and fear as a catharsis. While tragedy can be fascinating, few would admit that they actually like it; that considered, the inverse applies, it is possible to like something while not particularly enjoying it. Hedda and George perfectly exemplify such a philosophy; the audience may like George, but they are probably more fascinated by Hedda.

Along with the other traits previously mentioned, something that makes George likable, perhaps even subconsciously, comes from his productivity. George spends the play doing, he makes a concerted effort to build — or rebuild. He spends the entirety of the play trying to build his marriage and his family, he tries to build a home for said family, and build a career. George 
attempts to establish himself and his family among society, he remains proactive and positive. He writes (builds) a book on a subject for which there is no doubt comparatively little research, and in doing so he becomes a productive and active member of the research culture, because "one must keep abreast of what other people are writing." He tries to build relationships as well. He wants Hedda to become close with Juli because they both have an important place with him and it will help strengthen the family bond. He tries to rebuild his friendship with Eilert. When George hears Eilert returned to town he becomes excited to send him a letter and have him over — so much so he forgets about the party in his honor. In fact, the impetus for rebuilding the relationship comes when Thea seeks him out specifically to help her rebuild her own relationship with Eilert. Lastly, at the end of the play we see George quite literally rebuilding Eilert's lost book, and in the process (re)building a relationship with Thea.

While George spends the show building and doing, most other characters spend their time destroying, or undoing. Thea destroys her relationship with her husband and step children, Brack tries to destroy Hedda's marriage, Eilert destroys his book (figuratively) and his reputation, and Hedda destroys as much as she possibly can, even herself. The audience, justifiably so, becomes captivated by this destruction, it is interesting and on a certain level, enjoyable; as good dramatic writing should. It creates tension and intrigue, and most importantly it sets up a conflict of interest and principle between George and all of the other main characters. Luckily for George much of this destruction by the other characters, goes unnoticed by him. Not because he is aloof, but because they carry out said destruction in a surreptitious and deceiving way; which, in and of itself, adds something else to the list, trust. Not just trust between the characters themselves, but between the characters and the audience also. As stated earlier, the audience comes to believe that George is a reliable person, and soon thereafter Hedda proves herself unreliable-or at the 
most, reliable in her unreliability. After seeing Hedda's dishonesty, Brack's sliminess, Eilert's weaknesses for both drink and promiscuity, the audience cannot "believe in," much aside from George. Fascinated by him or not, he is dependable, trustworthy, and a person people like, even if not actively enjoyed.

\section{George as a Humanitarian}

"They do not fear to pass from thought to deed." -The Feast at Solhaug

There is more than just the actions one takes in achieving their objectives or overcoming their conflicts which gives them status in life or literature. It must also be considered how they treat and influence others. George is nice and dependable, but insofar as he presents such qualities outwardly, he also searches for similar qualities in others-and often finds them even when they are not altogether apparent. George humanizes people, which becomes more and more clean when seen against how Hedda's uses people as toys. George's scholarly approach to life helps define what sets him apart, but the rationale, the cerebral recognition helps him be the person he is, and to find that person in others. To Hedda, people merely subsist as play things, something used for entertainment and discarded once bored, but to George people are truly human beings.

Aunt Juli describes Lovborg as George's "most dangerous rival"-either in a professional or dramatic sense, but it does not take long to see that George has great concern for Eilert, even if a bit jealous of him. George appears genuinely happy that Eilert has seemingly turned his life around for the better. He cannot wait until he has the chance to see him again, even after he learns Eilert might compete for the same job as him. To George, Eilert is more than just a rival 
writer or rival suitor, more than someone vying for the same professorial appointment, Eilert is first and foremost his old friend, something no one else-with the possibility of Thea, seems to consider Eilert. George fully intends to return Eilert's lost manuscript, despite the probability of it becoming the book that will forever overshadow him, and he even keeps its loss a secret from others to help Eilert save face. Finally, in the end when George devotes his life to reconstructing Eilert's book, he does it for the sake of Eilert's name, not for his own gain, or even because he thinks it will make a fantastic book, it is because "I owe it to Eilert's memory." Which says a lot, since he, of all people, does not necessarily owe Eilert anything.

In a brief moment during Act IV George offers a glimpse of how he sees Berte, and how he considers her more than just a servant. When George celebrates Hedda's pregnancy, she says, "quiet or the servant girl will hear you." George responds with some indignity, "servant girl?

That's Berte, I'll run out and tell her right away." George would not dream of considering Berte as not part of his family. She helped raise him after all, and he insisted that she come to his house when he returned from his honeymoon. Most likely he wanted Berte there in case his suspicions of pregnancy turned out true, so the child could have Berte in their life like she was for him.

\section{George's Connections}

\section{“How can I hold you close enough"-A Doll's House}

George has a sincerity that contrasts nicely with most of the other characters in the play. George essentially serves as a foil for Hedda (or Hedda the foil for George) but he connects to every other character on a level that even Hedda does not achieve. In fact George foils well for 
the other two men also, and the plot more or less centers on the differences between him and Hedda. George is scholarly and research oriented, Hedda finds research and "musty old libraries" boring to the point of tears. She questions the amount of books he owns when he brings some home even though research and writing literally affords them their lifestyle. Meanwhile having two pianos and a liveried footman for herself does not raise a single question. George has a strong relationship with his family, (what is left) but the text makes very little mention of Hedda's family outside of brief remarks about her father; and Hedda certainly does not want anything to do with George's aunts. George is deliberate and analytical with his actions, even when drunk he takes the time to think something out before he acts; he has the wherewithal to have found Eilert's manuscript and not given it back to him while so inebriated, and to make sure others do not know of Eilert's carelessness. Hedda, on the other hand, is the epitome of impulse and passion. The ramifications of her actions receive no consideration before she does some-thing, and if they are, she considers them with a deliberate disregard for repercussion that might affect herself and those around her.

George's connection with Thea is not developed all that deeply, but from the little information given about their past, they must have, and had, an amicable relationship. After all, Thea comes to seek him out personally, while when George hears of Thea's arrival in the city, he becomes giddy in a reminiscent kind of way. Combine this with the eagerness both characters share at the end of the play when they agree to work together to rewrite Eilert's book and how George offers Thea a place to live not fully knowing the details of her current arrangement, it is clear, while a while may have passed since they have seen each other, their bond remained strong, and in little time it begins to reform itself. 
In the first scene, long before we see, or even hear of Eilert otherwise, Juli says flat out that Eilert is George's rival and enemy. Despite that, George asks Juli if she has heard any news about him, and expresses concern for his old close friend of his. Later George invites Eilert over to see him again, Eilert comes to show George his new book, and mainly because he wants to see Hedda again. When Lovborg arrives at the Tesman's, George is overjoyed to see Eilert again, and it does not take long for them to pick up where they left off however many years ago. The fact that Eilert wants to show George his new book before anyone else, and even asks for his input, then just a few minutes later degrades him while speaking to Hedda shows how little respect Eilert has. Then, in Act III George calls Eilert's book the greatest thing ever written, George's respect for Eilert has only grown over the course of the action, and by the end we see Eilert's behavior taking on a much more impulsive characteristic pitting him solidly at dramatic odds with George. While he finds Hedda irresistibly compelling, Eilert knows a relationship with her would be wrong and ultimately, he may cause George to "lose his child" in the same way he caused the loss of his own child, his manuscript.

Brack remains something of a mysterious figure in the story, and while there is not really anyone Brack has allegiance with other than himself, he shares a friendly but very guarded relationship with George. Likely the only honest reason Brack offers up his money to pay for the Tesman's house is to set himself closer to Hedda and earn her admiration, but George and the judge must have had a good enough relationship beforehand in order for the topic to come up. Brack is older and nosey, for lack of a better term, George, younger and less concerned with things outside of his business. Brack has money, whereas George, for now, has little wealth, Brack holds respect in the community and paired with Eilert they represent the two extremes of the public reputation spectrum while George sits in the middle. Perhaps most importantly, 
though, Brack, like Lovborg flirts with Hedda, something George is not keen with, and he vies to obtain that which George already has and does not want to lose: Hedda.

\section{Making Strong Choices}

\section{“Choice is calling! Hear'st thou now?" -Brand}

Making theatre is about making choices, the stronger the choice the more impact the outcome has on an audience. Part of the beauty of making theatre is good plays have a way of remaining good because as stories live on through society's changes; the context can shift and different discoveries will happen without losing the original intent of the playwright. Do I think that Ibsen intended everyone to see George the way I see him, or that everything I am writing about was done deliberately to purposefully construct a very specific character? I will put it this way: the chances are a million to one, but not impossible. Regardless of the specificities Ibsen had in mind, the truth of the discoveries are no less valid. Strong choices make a good play, and the choice to see George as a character beyond the bounds of his contemporaries makes for a stronger choice than one to play him as a meek, domestic peon. As Sanford Meisner said, "courage means willing to risk everything." Ibsen wrote a family drama, one that calls into question gender roles, relationships, and perception, building powerful forces that oppose each other only serves to make each character stronger and the message more resolute. Hedda is a force to be reckoned with to put it mildly, so she needs someone substantial with whom to contend. Though he loves and dotes for her, George provides that substance. Brack and Eilert ultimately accomplish nothing. Hedda's actions seem frivolous if all of the men in her life are simply her puppets. To drive someone to do what Hedda ultimately does requires the concussive 
blast of an unstoppable force meeting an immovable object, not simply experiencing a little resistance and running oneself off the edge. 


\section{ACT II - The Show}

\section{The Great Pretender}

“Oh, you needn't pretend ignorance”-The League of Youth

Something else which provided me with a challenge was navigating the topic of George's obliviousness. As I discussed earlier, George cannot be totally unaware of all that goes on around him; he must know more than he makes known. So then come the questions of why he pretends, or puts on this facade of obliviousness, and how does one go about portraying that facade on stage. Firstly, as previously stated, the best way I found to depict accurately characterization ultimately lies in simply playing the truth of what is written without dwelling on whether or not the audience picks up every single bit of subtext and character detail. The playwright weaves together the strings of storylines, and the actor must then cast the net to ensnare the audience. Frankly, though, it does not matter how big of a net one casts, something will inevitably slip through the holes. In any case, given circumstances are an actor's best friend; and the given circumstances here apply to both the explanation and possible depiction of George's mask of unwittingness.

The text makes clear that George has very particular focus and interests and that often these interests command preference for his attention. In fact, his focus on his profession distracts him a number of times throughout the play. For example, after learning he must compete with Eilert for the professor position, as Brack is leaving George says, "Oh, yes, yes; of course. Sorry, I am at sixes and sevens just now" (Turner 31). The sentence begins with "oh" and three words of affirmation connected by three bits of punctuation follow, which makes it stand out amongst the dialogue. As an actor I look at any irregularity in the text as an indicator of circumstance; 
repetition and excessive punctuation exemplifies such an indication. This compounded with the fact that following the irregular line of text George apologizes and even says he is "at sixes and sevens"- a phrase used to express confusion or disarray, makes George's distraction clear. His attention leaves the acting in the current moment and shifts to the thought of losing progress on his work, or even worse, the stability of his relationship with Hedda. George is not oblivious to what is happening or to those around him, his immediate response to Brack, while irregular, is clear and present. His thoughts just focus so intently on his passions that it can appear he does not notice his surroundings. This gives me a lot of circumstances to consider and act out in that moment that will indicate to the audience that, while distracted, George keeps an awareness about him. Breaking it down into smaller given circumstances makes it easier for me to build the puzzle by specifying the pieces.

Throughout the play George exhibits signs that he does not like to engage in confron-tation on any level. He avoids a number of situations that might put him on the spot or where he could possibly make another person upset or uneasy. For example, his panic of needing to compete for the professorship stems from his fear of confrontation, especially when he learns said competition is with Eilert. Competing with Eilert would result in a no-win situation for George. Either he loses out on a job which is important to him financially and fundamentally, or he runs the risk of creating a permanent divide between him and Eilert, separated by jealousy, guilt, and a sense of betrayal. Granted, some time has passed since George and Eilert spoke, but good friends often remain so as they age despite going through intervals of separation; life gets busier as people get older. Another no less significant, and more prevalent illustration of George's fear of confrontation reveals itself through his inability to plainly broach the topic of pregnancy with anyone, even his own wife. Which I found helped me to motivate his exuberance 
when, after so many attempts at carefully navigating the question, Hedda tells him without him needing to ask.

Making a good connecting with George's aversion to confrontation helped me with the characterization in a couple of ways: potential confrontation clearly signaled changes I needed to make in George's behavior, but most importantly, it further elevated the apex of his character arc during the confrontation with Hedda in Act IV that further provides significant evidence of his transformation. I found execution of that scene difficult even with all the connections I made with the character, the oscillation of emotion adds a great deal of weight to an already heavy moment. I could not have felt comfortable in that scene, yelling, chasing, and even grabbing Hedda without knowing the fact that he engages in confrontation at all, means he has gone past his personal boundaries.

\section{Looking Back}

“Spectacles of experience; through them you will see clearly a second time." -The League of Youth

Some actors may go their whole careers without a chance to play an important character from an iconic play, so I recognize my luck to have a chance to do it twice. Hedda Gabler is a foundational work in realistic theatre, and while the play and the title role get a lot of attention, George Tesman goes underappreciated. In fact after having played him a few years prior to beginning my MFA, I hoped for the role of either Eilert or Brack, but given that I'm not much of an Eilert type-wise, I was almost sure of getting cast in the part of the Judge. Much to my surprise, however, the director called upon me to reprise my role as Tesman. While at first a 
slight bit downtrodden not having the opportunity to try on a different role, I soon realized I had been given a second chance to really take the time to appreciate an undervalued character.

A quick look at the recording of the previous performance, produced by Slipstream Theatre Initiative in Detroit, Michigan, will tell you that though the two productions were of the same play, they were vastly different shows. Slipstream's production, like most of their shows, received heavy adaptation in an attempt to make the show a bit more accessible to a more modern, younger audience likely not used to a traditional period piece-type show. The most important aspect of the adaptation was that three women at once played the role of Hedda, each women representing a facet of Hedda's personality that connected to each of the three men in the play, George, Eilert, and Judge Brack; the wife/daughter/mother, the passionate romantic, and the frivolous society woman, respectfully. The men, all three, were directed to acknowledge only the actress playing the Hedda who corresponded to their character, so as George, I only interacted with, or even looked at (until the very end) the women playing the "wife Hedda." A difficult thing to do, putting my training and instincts aside to not give attention to those speaking on stage, not to mention focusing all of my energy on a single facet of the character, but ultimately, as with every challenge in theatre, it made me a stronger actor. That said, it was not until delving into the character at WVU that I noticed how much of a disservice the concept-driven Slipstream show did to the character of George. Initially, I thought that doing the show in a more traditional way would not make too much of a difference in what I did to develop and portray George, but after a few rehearsals it quickly became apparent just how different it was.

I found it difficult to reconcile George's feelings for Hedda when only connected to one of the women at a time. While interesting and stunningly compelling, blocking the other facets of Hedda's personality from George changes his behavior. George has to notice and contend with 
all three sides of Hedda: the wife, the passionate woman, and the lady of society; it makes the action of the play more understandable, and it gives George the robustness he might lack otherwise. When he only sees one side of Hedda, then he plays the role of "just" the husband, but when he sees all sides of her, he is a husband in addition to other things. A husband who wants to connect with his wife's romantic passion but unable to, seeing instead the fire burn in her eyes for an old flame. Someone who wants to provide her with society life, and amenities beyond his current means. A husband who sees his wife unconnected to her family and hoping to raise a family of their own, and give her the chance at a relationship that he feels she missed. The tension within George does not have a chance to build in the same way, which makes his thinking process seem more trivial and capricious; that makes him look aloof and disconnected like so many see him. I learned important things about his relationship with Hedda, as his wife, from the Slipstream production, but there are things I lost concerning his relationship with Hedda, as a person.

Another thing of note concerning the former production was that we cut back on George's verbal tics. ("You know" in this translation, "Eh" in the first) They get in the way of the dialogue, particularly with a more contemporary aesthetic, and without the context of George seeing the breadth of Hedda's character, they seemed more like a gimmick than an important part of his personality. Looking back the tics are something I wish we would not have changed, those exact kinds of challenges enable actors to grow within the art form. They force one to look at different perspectives and try different approaches, to make justifications based on the world and other characters around them, and most importantly they provide the actor with chances to take risks. One can play George Tesman in a very "safe" way, and while that might end up fine for the production, it would not be fine for the process and growth of an actor. Innovation is the 
byproduct of problem-solving, if the actor is always safe and never deals with challenging problems, they will miss opportunities at discovery, revelation, and improving their craft.

\section{Driving the Plot}

\section{We hold Fate's reins, we drive her hither, thither"-Love's Comedy}

A strong main character drives a play's plot, their actions are not dependent on the events of the play, the events move because of their actions. As John Galsworthy wrote, "The dramatist who hangs his characters to his plot, instead of hanging his plot to his characters, is guilty of cardinal sin" (Cole 48). Instances of a character driving forward shows that character's importance and helps signify and strengthen them as a capable protagonist. My job as an actor is to do justice to the playwright's intended message, however, it cannot always be known exactly what the playwright intended. Inference and comparison will usually suss out the meaning, but after decades, or even centuries, of a play's existence, the meaning and characters could shift through new context. I try to make every character I play as relatable as possible to the audience while trying to uphold what I (or the director) believe the playwright endeavored to say. In the case of Hedda Gabler, Ibsen's attempt at illustrating the tragedy of real life and it's people, exceptional and unexceptional alike, can unfold in a number of ways. Most commonly we use Hedda as a vehicle to reach the story's destination, but George, too, propels much of the action forward in meaningful and crucial ways.

Perhaps the most important moment in the play's plot happens when Hedda burns Eilert's manuscript. Hedda herself makes the decision to destroy the manuscript and the action is hers alone, but she does not come to that decision solely on her own. In fact, George's actions 
precipitate most, if not all, of Hedda's behavior during the course of the play. One could say, Hedda's actions are simply reactions to George's momentum. Hedda explains to Brack in Act II that the making of her "bed" which she now "must lie in " started while George spent the summer seeing her home from parties and trying (desperately) to flirt with and impress her. Now, sure, a line must be drawn somewhere, else we could trace responsibility for the play's events back to their great, great, grandparents and beyond, but when looking at the primary cause of the major effects throughout the story, George's actions lie at the root. George's determination to buy the house they live in leads to anxiety over securing a good enough job to pay the debts they now owe, and because Hedda never actually cared for the house in the first place, it contributes to her overall unhappiness with life. George's focus and dedication to his work, which requires constant research and time-consuming undertakings like obtaining a doctorate, drives Hedda to second-guess their marriage and compounds her doubts with boredom. Additionally, George inviting Eilert over, or helping in persuading him to attend the party, or his interest in Eilert's book, or finding it on the road and not immediately returning it, (due to fear of confrontation I might add) or, perhaps most importantly, leaving it in Hedda's care, are all major actions that, lead to Hedda burning the book. While, in hindsight, George's actions may not surprise the audience, they are certainly unpredictable.

While actions typically drive a plot, active inaction can also have significant effects. In this, too, both Hedda and George take blame, but ultimately, Hedda's behavior is better described as a reaction to, or the effects of George's (in)action. Plainly, Hedda feels emotionally alone. She is a being of passion and impulse, and George simply cannot, or will not, satisfy that hunger in her soul. George's inability to provide the social life Hedda desires also affects her disposition. The lack of society and amenities amplifies Hedda's boredom and displeasure with the situation 
in which she now feels trapped. In addition to the emotional abandonment she feels, at the end of the play George becomes physically absent, leaving Hedda to the company of either an aunt which she dislikes or a letch which she distrusts. The product of these inactions cannot exist without purposeful action undertaken by the actor playing George. I am often intimidated by the responsibility I have as an actor to devise, engage, and justify the actions of another person's work of art, but it helps to consider the product as a whole, gaps included; after all, a net would not be a net without its holes. Over the past three years one of the most important pieces of knowledge I have gained is knowing that every step counts towards something, and a missing stair just means the following step must be strode farther.

\section{Dealing With Odd Language}

“Again those terrifying words!" -Catiline

When the WVU cast read through the script at the first rehearsal in mid January 2020, it was the first time I had read an unadapted version since 2012 while an undergrad. I did the play with Slipstream in January/February of 2016, so the overall story and basics of the characters remained in my head, but since it was so heavily adapted I noticed specifics that I had left out of mind; one of those specifics, as a mentioned, was George's verbal tic, "you know." So, from day one the tics became a sticking point in my exploration of that character. I could not ease out of them, or trivialize them this time around, I had to justify them all. Early on, the director, Robynn Rodriguez, insisted I give each one a specific meaning, I may reuse meanings, but I needed to make sure I knew exactly what each one meant. We likened it to approaching Shakespeare text, the actor must be fully aware of exactly what is being said for the audience to follow along. The 
only difference is that Shakespeare is a fun challenge in that regard, here, "you know" over and over again just felt daunting. Since we decided that they all needed purpose, they are not something that George did uncontrollably or unconsciously, there had to be a reason; Ibsen must have written them for a good reason, so I had to say them for a good reason. That sent me down a path aiming to show that they each had a purpose. George says "you know" 71 times throughout the script we used. He has a total of 296 lines in said script, which equates to roughly one "you know" every four lines. When you really think about it, saying the same phrase (phrase, not just a single word) so often is quite outside usual speech patterns, so giving each one a specific meaning certainly provided a challenge. A challenge that I am still not one-hundred percent sure I managed to meet, but it is about the journey, not the destination.

I decided on categorizing each of the "you knows" into different categories, or reasons why he might say them. I found many versions of "you know" in the script, some with periods, others question marks, some coming before dashes, others after, quite the variety with which to work. No doubt some of them served simply as a kind of word punctuation for whatever George said, much like a contemporary person would say "ya know" or, "or whatever," so those went into the punctuation category. The next category I looked to fill I called the insecurity category. Often George says "you know” as a way of seeking approval, again, similar to how someone today might say, "ya know?" I had to categorize them differently than the punctuation "you knows" because of their context and sometimes the use of a question mark in the text. That one little question mark added to the end of a line of dialogue can make all the difference in the world; there is a big difference between asking something and telling something, especially in George's world since telling is not something he did often. The third category I named the anxious category. Some "you knows" seemed as though they may fit into both the insecurity and 
punctuation category, but it did not feel right while in the moment that he would finish a statement and seek approval at the same time. The anxious category was George filling in the space because he felt like someone had to say something. The awkward silence breaker, if you will.

After plotting out the "you knows," then trying them on for size during rehearsal, some inevitably changed. Sometimes they changed based on the normal progress one goes through during rehearsal, but some had to change based on what the other actors brought with their characters. So early on, keeping track of what "you know" came where, and which context I needed to use for this or that proved a chore, but the more I learned about the characters, and myself, the more natural it became. I set a goal that by tech week I would not even have to think about the "you knows," to make them second nature due to tuning in with the character and the world. It is hard for me to say exactly when I reached that point, which probably makes a good comment, since that means I was not thinking about it, but I definitely felt comfortable with them by tech week.

\section{Traditional Staging}

"Our faith and custom from the olden days" -The Burial Mound

Period pieces can offer quite a challenge, especially when you are dealing with something so realistic as ... well, Realism. When staging a play today that is set in a much different time, the audience needs to maintain a high level of attention to everything on stage as some of the action and language could be unfamiliar to them. So the utmost of clarity is required of the cast to allow everyone to follow along while keeping the action as close to an original presentation. 
The most glaring details to maintain come from the design elements, costumes, set, props, etc., so that what happens on stage looks authentic to the audience. Most people may not think about the performance elements the actors must deal with during a play set in a different time or location. Use of an accent would quickly indicate a specific region, but more than just how the words sound, attention must be paid to how the words are said.

The first performance of Hedda Gabler was in 1891, and originally written in Norwegian. So not only does the translator have the job of translating languages, but time periods as well. Additionally, in the Nineteenth more formalized writing was common compared to the popular writing of today, and regardless of how the general population spoke playwrights used a formal tone for dialogue. So the translator, in this case Jerry Turner, needed to find the best possible way of saying something in another language, despite how tricky the phrasing was written, all while trying to maintain the style in which Ibsen wrote and how he would expect the speech of the actors and characters to sound. Then, as an actor, I must take this delicately wrought translation and present it so that our audiences can understand exactly what is happening and being said while maintaining a high level of authentic period appearance. An example of something I often struggled with early on was not clipping off the endings of words like many do in today's colloquial speech, e.g. "the dog is beggin' (instead of begging) for people food," or "where are you goin'." Just kicking the habit of wanting to shorten words offered enough strife, not to mention we then needed to make it sound natural. When forcing yourself out of your normal speech patterns words can come out sounding a bit mechanical. I heard a lot of emphasized hard ' $\mathrm{g}$ ' sounds happening at first, but after a few weeks of repetition, and, like most things having to do with acting, once I stopped thinking about it, it started to flow more naturally and sound authentic. 
Posture and body language is something else that I had to consider; if Ibsen wrote in a formalized style, and the actors spoke as such, their body should match their voice. George maintaining a formalized posture, especially in front of house guests, not crossing your feet at the ankles when sitting, and the general way in which clothes are worn were the stickiest habits to try and break. Not slouching and crossing my feet subconsciously when sitting contributed to a large part me strife, especially when I was not in rehearsal and therefore not thinking about those things. The costumes helped me considerably, though, with the process of learning new body language. While wearing something that feels foreign it becomes easier to keep physical habits in check. The costumes, in my limited knowledge of dress in the 1890s, were largely period accurate. The women all had to wear corsets, and the men all wore specific stiff-collared shirts, suspenders, and pants pulled up to a level that defies any perception of comfort. Those three details, while not terrible - especially compared to what the women had to endure, worked better than enough to put me in a body-set that kept my physicality in proper order.

Beyond just appearances, the content of the play provides a challenge as well. The fact that George does not have much authority in his own home was a provocative idea to people in 1891. Society expected women not behave so independently, and if they did, a husband would surely try to stop it as soon as he could; "gender and comportment were intimately related in the 1890s" (McLaren 8). So, here we have a couple who act completely out of concert with what society would expect of them, and they treat it as perfectly normal. George is a rather progressive husband, and whether he consciously behaves that way does not matter, what matters is that Ibsen consciously wrote him as such. So the whole cast faced the challenge of trying to convey a societal convention from over a hundred years ago to a group of college students without just flat out telling them the unusualness of the family dynamic, and how what we are doing comments 
how gender roles should not matter." The best way I found to easily convey such a message: not focus too hard on conveying said message. One of the most valuable things I have learned over the past three years allows the actor to step back and let the script do its job; good writing will do the heavy lifting, the actor just needs to supply the heavy for the writing to lift. A lot of my growth in this program is centered around an ability to let go and live the truth of the situation. I used to try too hard to live the truth, and when it did not seem truthful, I would force it, and looking back I can tell my performances suffered. The first time I played this role I forced parts, absolutely, this time I did not need to force anything, and the difference between the feeling was like night and day. The best way to express how George does not concern himself with stereotypical gender roles is simply not play George's consideration with gender roles. Similar to the adage about how comedy is funny until you try to be funny, the same idea applies to all genres. The audience will pick up on the fact that George differs from the typical husband, the actor just needs to convey that George lives his life with an atypical normality he does not have to think about. He does not plan things to do or actions to take in order to rail against the oppressive system, he just exists as himself.

\section{The Struggle with the Translation}

\section{“Speak your meaning more clear councilor.” -Lady Inger of Oestraat}

Now that I've said a bit about the translation, and how challenging it appears for the translators, I would be remiss if I did not mention how badly I struggled with the translation in the script we used. I do truly respect those who translate works of art so that people around the world may enjoy them, and Jerry Turner provided the theatre community with a new version of a 
work of art, and for that he deserves recognition. It was, however, a frustrating version to deal with from the production side. Formality and aesthetic seemed like Turner's primary focus in his adaptation, using language as traditionally as possible. Writing was generally more formal in Ibsen's time, so I pay kudos in that regard, but one can adhere to formality without sticking to antiquity. Today's speech contains formal words and phrases that sound more natural to today's audiences.

A good example of fighting the translation happens in the climax during Act IV. George gets angry at Hedda and shows any real, profound emotion, for the first time, and in the midst of this emotion he says "good lord above, woman. No, no this is impossible!" (Turner 83). That line sticks out of the dialogue like a sore thumb. No cadence, no drive, no inflection could have made that line sound natural in the midst of such an argument. Regardless of how it sounded to the audience, it would constantly put me back into my own head. I would spend approaching lines anxious and unconfident knowing what was coming, then I would spend the following lines disappointed in myself and losing momentum. At first I chalked it up to Turner attempting as literal a translation as possible and not taking liberties with the language. Respecting that, I thought the fault landed on me as to why the line sounded and felt wrong. The necessity of literal translation could not work as an excuse, however, as I would come to find out there are a great many phrases in the script in which Turner takes liberty with the wording. "Good lord above, women," among others, became such a bump in the road I looked in other translations to see how other writers translated that line. Much to my distemper, I found that no two translations (of the handful I came across) interpreted that line in the exact same way. The director insisted I keep the line as scripted, and not one to back down from a challenge, I said it every time; each time in 
an attempt to sound different and better than the time before. I never truly found comfort in how I delivered that line, though, and to this day I would still dread needing to say it believably.

While an actor tripping themselves over the translation certainly burdens them, it is not something that likely terribly affects the audience's understanding of the show. They may take note of a weird-sounding phrase, or of the actor losing their stride, but if at that point in the play, a short, silly phrase makes enough of an impact to take the audience out of the performance, that actor has bigger problems on their hands. "Good lord above, woman" is just one of many examples of qualms I have with the translation, some small, others a significant game-changer. My second issue with the translation lies somewhere in between, causing a brief lack of focus and total misinterpretation. Turner was quite inconsistent with contractions in the script. Not using contractions helps to indicate formalized speech, but the script contained many contractions which surrounded their non-contracted counterparts. Words like "I'm," "can't," and "you're" are represented both ways, and upon further inspection, there is no apparent textual justification for this. I thought, perhaps, characters would use contracted words in a more familiarized conversation and break them apart when engaging with someone on a more formal level; or perhaps only certain characters would use contractions. No examples of such consistency existed, though, and there are even instances where both versions get used by the same speaker on the same page. When trying to force myself into a different way of speaking, an inconsistency with what I need to say can throw off rhythm and make it that much harder to not subconsciously simplify words. Also, the audience tends to pick up on irregularities, and even if done on a subconscious level, it can affect how they see and reflect upon the play.

The third, and most important translation issue to touch on concerns the interpretation of a specific phrase meant for wordplay, and to provide a double meaning in a dramatic moment. 
George has a line in Act IV after learning about the pregnancy that carries significance and presents wit. The line, when translated literally, means "you burn for me," but the translation (and actually most translations) reads “you love me." Both of those phrases colloquially can mean the same thing, but therein lies the wit. Hedda just literally burned away a manuscript which a man finds precious enough to call his child. George, on the other hand, actively tried to avoid the manuscript from being lost or destroyed. This moment not only marks a turn in George's character arc and sends Hedda's character decline plummeting into the abyss, burning of the manuscript and the resulting argument finally bring the couple's fight into the open. The audience sees how much distance they have between each other, and how much that can impact George. In the matter of a few lines George goes from his happiest moment, his fatherhood, to recalling his darkest moment, the destruction of the manuscript, and more the betrayal, by the very person he loves most of all. It is damn good writing that translators absolutely throw away, and not even mentioning the loss of such a priceless pun. Regardless of whether you agree with my sentiments above, or you think George really believes Hedda loves him, to lose such well-woven wordplay can only hurt the script.

\section{The Student Experience}

“I should study past ages and times voracity? Ay, sure enough; that is the thing for me." -Peer Gynt

I make it a point to learn, or at the very least hone, skills with every show I do, acting or otherwise. I see the importance in(as should every artist) continuing to grow, as an actor or in any area of theatre arts, throughout the rest of my life. Realistically, a perfect performance or perfect show does not exist; any character, any script, any production element can be improved 
upon somehow. One of the most beautiful things about theatre is that it exists on a temporal plane aside from its physical manifestation, so there never exists just one version of any show — and the more popular or important the work, the more versions we see. A production done badly is forgettable, it can fall into the wastes of history, over and forgotten; a show done well lives-on fondly and memorably, but regardless of whether the show is deemed good or bad, it grants a learning experience to the artists for their next time. I like to think of all of the roles I play as chapters in the story of my own life, each character adds experience and understanding to my acting repertoire and the way I see the world around me. Each production I am in differs from the last, characters come and go, but it all leaves a mark on me as an artist and a person. So, it is important that I make each one of those experiences matter, not just as an accumulation of memories or experiences, but as an important, functional addition to the quality of my craft.

The biggest advantage I had going into Hedda this time around was going into my second year of training in an MFA program while working on the show. Rather than just $a$ goal, it became the goal to learn from the experience. Over the course of my time at WVU one of the most important changes I have made as an actor pertains to worrying too much about the final product. Doing that only serves to get in my way, as an actor and a student. One can easily say college is the best place to take risks and if you are going to fail, college is the place to do it, so fail big. While true for the classroom or perhaps lab shows, It does not, nor should it, apply to the official productions. In fact, it took me far too long to grasp the difference between the work and the product. People say to accept failure as a nice way to imply making excuses for poorly done theatre. In actuality, I have found college provides the place where one has the best chance of succeeding, not failing. I don't mean to say college theatre never fails, but, extenuating circumstances aside, it is not done "poorly." Academic programs give each production such 
scrutiny that multiple people deliberate for a long time just picking a season. Not only do they take into account marketability, but shows are chosen based on the strengths and weaknesses of the program's student body. Furthermore, the faculty overseeing the production has an obligation to not only their careers, but to the students under their guidance and the image of the program as a whole. Not only are there generally more resources and opportunities to lend better attention and focus to the production, but the attention can come from numerous directions and disciplines with varying ideas and perspectives.

For the process of Hedda, indeed every university production I have done, we had ample preparation time, extensive rehearsal time for table-work, dramaturgy from students and professors, opportunity to work related subject matter daily in classes, multiple ASMs to provide detailed notes on lines, blocking, etc, the opportunity to rehearse for more than just a few days in the actual theatre space while the designers build the actual set around us, an overabundance of rehearsal time, (double-edged sword) all of the rehearsal props and clothes needed — and the list could go on. In my experience professionally, one needs the luck of a clover to have all of the same amenities that college productions provide, even when under contract. Perhaps the most important thing which a college environment provides comes from the sense of familiarity, camaraderie, and collaboration among those involved. I worked with people I know I can trust based on personal, sometimes varied, experiences. Theatre epitomizes the essence of collaboration, and rarely does collaboration exhibit itself as well as it in academic theatre.

School faculty members direct most shows, and in most cases I have had them as professors, allowing for the trust and familiarity I mentioned to flourish. Sometimes, though, guest directors come in to helm a show, in which cases the trust needs to build from ground level as the show develops. The director for Hedda, Robynn Rodriguez, was brought in as a guest 
director, but I had an unusual opportunity to build more trust with her outside of rehearsal. For the duration of the process, six weeks or so, Robynn took the grad students on an exploration of Shaw in the classroom as a guest instructor. She dealt with Shaw in the same way she dealt with Ibsen, which makes perfect sense, and in doing so I gleaned knowledge and experience on the subject of early realism coming from the same source as the direction for the show. I felt intimidated at first to open up the work side of myself to a new person who was firstly responsible for me achieving a good product, but like with other professors, time in the classroom expedited the levels of trust. In fact, if it wasn't for the classroom experience with Robynn, I would have found it difficult to build said trust, both with her and in her. I thoroughly enjoyed the work we did with Shaw pieces, and she excelled at laying everything out from facts to insights, and penetrating to the core of the material. Her attention to detail combined with experience made discussions engaging and informative, and my scene and monologue work fruitful. In rehearsals, however, the passion with which she approached her work had a different energy. In plain terms, she became difficult to work with as a director but lovely and engaging as a teacher. I see this as a great example of the separation between acting work and acting product, and something that seriously helped drive home the work/product concept for me. In the classroom it was okay to be wrong at first, or to spend time searching for what needed finding; in the theatre, however, there was little time for either. Rehearsals felt like going to a job I had lost an interest in, a feeling of burn-out washed over me each night despite not actually burning out on anything at the time. Thanks to the work in class, though, I could see that the way she directed came from a good place, even though it did not always feel so nice.

This production offered me great opportunities for growth as a theatrical practitioner beyond just an actor. A practitioner in the sense of a story developer, a storyteller, a student, a 
role model, a collaborator, a representative, and much more all rolled into one. This show challenged me insofar as it was the first time I had done early realism drama in late nineteenth-century fashion. I have done a number of early modern dramas in the past-Henrik Ibsen's A Doll's House, Anton Chekhov's The Seagull, August Strindberg's Easter, and of course, a previous version of Hedda to name a few, but they were all adaptations, modernized versions likened to the story from a century ago. We adapted the dress, the language, the settings, everything so a modern, younger audience would find the show more familiar and hopefully connect with it more. In a way, that put less pressure on me as an actor to accurately represent a character written so differently from myself in style and era. I know people in modern-day America, I'm familiar with how they talk, dress, carry themselves, interact with others, etc., so doing shows adapted for our modern audiences did not get me too far outside of my comfort zone, which ultimately, serves as a disservice to my growth as an actor. This show offered me a lot of opportunity to get outside of my comfort zone, which I appreciate more and more with time. Discomfort is the impetus of change and change leads (ideally) to progress, and when I am too comfortable for too long I get complacent and lazy, and as a result my work ends up suffering. Taking on roles with unfamiliar characters also leads to research, which leads to more knowledge and a better understanding of the world. I, like most others, had no idea where or what Brabant was, but the knowledge train that followed me looking up Brabant led to discoveries about this character I may not have made otherwise. Additionally, I now know about Brabant potatoes, which is a gift all its own. When I am outside of my comfort zone my attention shifts to surviving the moment, I am closer to the mindset of the character. When I'm too comfortable the majority of what I have to focus on concerns the performance itself, how I am 
acting, which inhibits the work. "In Other words, this work is UNCOMFORTABLE. It's about living in the unknown" (Silverberg 79).

\section{Acting Tools}

\section{"I have always been wary of acting on impulse." The Wild Duck}

When talking about realism, or honestly, acting in general, the Stanislavski system serves as an important foundation of what any actor does on stage. Finding the given circumstances for this show felt odd at first, because I had done a good amount of this work for Slipstream's George, the same character, but a very different person. Not fundamentally different, just outwardly different. For example, the Slipstream production made Tesman much less "geeky." Still scholarly and research-oriented, but he mixed that well with his social life, and others did not refer to him in a pejorative sense of academic. A huge part of the process was reevaluating his love for Hedda for this show. During the first production I succumbed to the belief that George does not love Hedda quite as much as he says (thinks) he does but sees her more as a victory for him. It worked okay for the show, but not so great for Tesman as an individual or as an interesting character on his own. As the show leaned on a concept-heavy presentation, trying to match any other one character with Hedda would have made things a bit cumbersome anyway. So for this production I had to dig for more details and root them all in honesty, George's honesty, not just imaginary truth. First and foremost he is an honest person, so it all needed real, profound meaning; his research, interest in Brabant and books, his compassion for and jealousy of Eilert, his connection with his family, and most importantly, his love for Hedda. A lot more work lay in store for me, but it certainly produces better results, beyond that, though, it provides 
me with a deeper connection to the art. As pretentious as that sounds I mean it, I appreciate this play much more than I did the first time around. Not for nothing, the Slipstream production had a brilliant concept and executed it beautifully, and chances are that most audiences, particularly younger ones, would enjoy it more than a traditional show; but having worked at the core of both productions I found a robustness to WVU's production that Slipstream did not achieve — particularly for theatre folks, and especially for the actors . . . with the possible exception of Hedda(s). "Love art in yourself and not yourself in art" (Stanislavski 250). That quote I would likely have dismissed as artistic pretension four years ago, but Stanislavski is the father of modern acting for good reason, because not only did he have the insight to realize such ideas, he also had the allsight to cultivate them in others.

After having gone over some Michael Chekhov work in class during my very first semester, it interested me that, despite never actually studying Chekhov before, a lot of the work we did in class seemed very familiar. I knew about Psychological Gesture as a concept, but I had never practiced it in technique. I had, however, done a bit of work with Rudolf Laban's methods, and the Michael Chekhov work slid neatly into the slots of space that Laban left unfilled. Psychological Gesture presents itself as a more characteristic and clearer version of Laban's system, or in other words, Laban is like the vocabulary while Chekhov is the action. Vocabulary I can do ... prohibitively so sometimes, but in the action I needed the work, and that's what the Michael Chekhov work offered. The two techniques were originally developed around the same time, but I would wager Chekhov knew of Laban and set out to economize what Laban was teaching. I discovered Psychological Gesture as something that really resonated with me, and the work felt familiar enough without overwhelming. 
The part of the Michael Chekhov semester that actually blew my mind centered around the exercises with the four elements. They were not described as such during the class, only described as molding, flying, flowing, and radiating, but it didn't take long for me to put together my experience with the work. In undergrad I had few acting classes, but the one that sticks with me the most was "Acting Styles" or something to that effect. In that class the professor, Malcolm Tulip, led us through essence exercises where our focus centered not on who the character was, but what the character was made of, and he simplified it into the four elements, earth, air, water, and fire. Since that class, associating a character with an element as their essence of creation set the foundation when I created characters. Essentially, I learned some of this work years before and practiced it over and over without even knowing. Unfortunately, the Michael Chekhov class only lasted half the semester, so we did not have time to delve too deeply, but it will stick with me forever. That kind of familiar work is nice to utilize especially when I am feeling out of my comfort zone, which, as stated, basically set the daily tone during this production.

Our work in the first year with Sanford Meisner's acting approach did not resonate with me as well as the Chekhov work, so I would not normally consider bringing Meisner into performance, especially when uncomfortable. Like with (too) many things, though, my epiphany of appreciation did not come as soon as I would have liked. While struggling with Tesman, an errant thought crossed my mind which made me think of Meisner and in that moment the work finally made sense to me in application. I stumbled upon it almost by accident when trying to invoke the behavior of the nineteenth-century European — whatever that meant. That word I used, though, behavior, set the action in motion, and in that moment it felt like tightening a loose bulb in a string of Christmas lights; the whole strand lit up. Granted, to my discredit, I have a short strand and the colors are not my favorite, but they are festive, bright, and beautiful against a cold, 
dark canvas. Sometimes when one digs deep enough into their tool box, they surprise themselves with how well a previously dismissed tool can work for a certain job despite how ineffective they might have felt with that tool in the past.

Much of the dialogue in this show contains round-about truths, half-truths, and even just plain lies. Ibsen provides all the details, "he registered subtle degrees of worthiness and unworthiness" (Valiunas 2), but leaves it up to the audience to suss out their meaning using subtext. The script is so riddled with subtext, as an actor I could not always rely on the dialogue to motivate my actions or initiate a change. Additionally, I need to provide my cast mates with more than just the words I say; regardless of how well the actors perform, the subtext, the deeper meaning as Meisner might put it, needs to present itself just as readily as the words. All good acting responds to behavior, but in a show like Hedda, behavior is particularly important. The actors must manage what their body language, facial expression, or tone says that their words do not, in other words they must behave in a very specific way; and of equal importance an actor must interpret, and thus react, to said behavior from others. It seems like Acting 101, and fundamentally one can draw similarities to Stanislavski's circle of attention principle of active awareness of your surroundings on as many levels as possible, but the main difference here, for me anyway, is the vocabulary used. The same principle said using different vocabularies can produce different results. Vocabulary can alter the way one understands something, either literally or figuratively, and the specific use of the word "behavior" for this show affected me in just the right way. To me, the word behavior, or behave, represents a specific type of decorum; when someone behaves I think seriousness, and important meaning, profound even, which differs from what I think when someone "acts" or "conducts." So just thinking of the word behavior helped to put me in the mindset I needed for the style of this show-conservative, proper, and 
traditional. More than that, though, really spending time looking at how the other characters behaved relative to the plain text allowed me to reexamine everything $I$ said and did. It forced me to consider the wants and objectives of the others and let George's perception of their needs have an effect on my actions, rather than only understanding my objectives and acting as if George affected only his own life.

A perfect example comes from Act IV when Hedda finally reveals to George (in not so many words) that she is pregnant. I struggled the most with this scene during my first outing with Slipstream, Hedda's behavior starkly contrasts to how George seems to understand the situation. The thought of parenthood torments Hedda while George welcomes the prospect, and if he remains unchanged by her behavior, the scene he enters the next, and final scene with less driving him to make and solidify his change.

HEDDA: Maybe it's time you did know, Tesman, now that-. [Breaks off and says violently.] No, I won't say it. Ask your Auntie Juli. She'1l tell you.

TESMAN: Hedda! I think I know what you mean. [Claps his hands together.] Good heavens! It seems impossible, you know?

HEDDA: Not so loud. The girl can hear you.

TESMAN: [Laughing with joy.] The girl? The servant girl? That's Berte! I'll run right out and tell her.

HEDDA: [Clenches her hands in despair.] It's destroying me, all this.

-It's destroying me.

TESMAN: What, Hedda—what? Are you all right?

HEDDA: [Now cold, controlled.] It's all—so absurd-George. 
TESMAN: Absurd? That I'm so happy? —Oh, I see. I won't say anything to Berte yet.

HEDDA: It doesn't matter. She might as well know too.

TESMAN: No. No, I won't tell her. But Auntie Juli has to know at once. And you, Hedda—you called me "George" for the first time, you know? It'll make Auntie Juli so happy, all this. She'll be so happy!

HEDDA: Will she be happy about my burning up Eilert Lovborg's manuscript— for your sake?

TESMAN: No, I'd forgotten about that. No one must be allowed to know about the manuscript, of course. But imagine, you're consumed by love for me, Hedda. —Auntie Juli must know about that. I wonder if young wives often feel such passion for their husbands, you know?

HEDDA: You might ask your Auntie Juli about that, too.

TESMAN: I will, as soon as I get the chance. [Looks uneasy and thoughtful again.] But I worry about that manuscript, you know? I feel sorry for Eilert. —Poor man. (Turner 41)

The text here seems clear-cut on the surface, but the behavior the characters exhibit here matters more than the words. Upon first, and second, and tenth in fact, glance I read this very much as George's happiness shining through Hedda's disappointment. His joy so overcomes him, he seems blinded from the behavior right in front of his eyes. Now, that interpretation is not 
necessarily a bad choice to make, and many would call it the correct choice, (if such a thing exists) but, plainly, it is not the strongest choice.

In my deeper examination of George I realized that he has stunted impulses when it comes to engaging with people on a social and emotional level, but that does not mean he lacks awareness of those around him. George perspectives things well and rationalizes better, after all; and even considering his happiness, acting the scene as if he simply does not understand how unhappy the whole situation makes Hedda-and ultimately how that affects their relationship, would give the actors, and even Ibsen too little credit. Hedda's behavior says it all. The line "I did it for you, George." follows the stage direction [represses an almost imperceptible smile.] It does not say smiling slightly or holding back a smile the language is specific because the behavior on that line needs to match the specificity. Hedda later says, "It's all-so absurd-George" but, again, the importance comes from how she says it and how behaves using the stage direction: [cold, controlled.] The act of someone calling your shared life absurd has enough of a sting on its own, but to do it in such a calm and collected manner shows how little they are affected by it. "Absurd? That I'm so happy? —Oh, I see." George responds, and there we have a dash marking a change of thought or discovery. What does he see; why does Hedda not want Berte to know? These questions wracked my brain until I examined the behavior on both sides of the lines and realized it was not about just Berte or Juli or Eilert, Hedda does not want anyone to know she is pregnant, not because she needs to hide it, but because she wishes with all her will that it was not true. George makes this discovery, the dash marks it, and the discovery tells him something that he himself wishes was not true: Hedda does not love him, she does not want to be married to him, she does not want a child, and she does not want the life he 
wants so passionately to provide for her. With that realization comes the weight of not just losing your wife, but having everything you hoped and worked for seem totally in vain.

Continuing with the rest of the conversation between them with the knowledge of George's discovery and the momentum of this behavior, the section reads differently. He declares he will tell his Aunt Juli because it would make her happy, the woman who raised him like a mother, happy about his child despite the child's actual mother not wanting it. An implication that Juli could fill the role of a mother figure which Hedda repudiates. Admittedly, the line "No one must be allowed to know about the manuscript, of course. But imagine, you're consumed by love for me, Hedda. —Auntie Juli must know about that." does make sense when read as George thinking Hedda really loves him and he cannot wait to tell Juli; but with that things do not sit quite right when analyzing it further and taking into account all of the behavior happening. Why would George feel it necessary to tell Juli that Hedda loves him? As far as Juli knows, Hedda does love him, and George knows as much, he propagated her knowledge. Plus, "consumed by love" comes after the revelation George has just had, but before the dash, which follows a period, yet the statement after the dash does not indicate a new thought or change in mood since he just mentioned how Juli's happiness in the line right before this one. So, George's behavior ought to remain consistent within the same beat. Things start to come together more when you cross reference other translations, they all phrase it a little differently but ultimately say the same thing, and still use the word "love." Every script except for the original script (and possibly scripts in other languages) which says literally, "that you burn for me." When asked by George why she burned Eilert's manuscript Hedda says, "I did it for you, George." If one reads the passage as follows: 
TESMAN: "Imagine you burning for me, Hedda." — change of thought"(No,) Auntie Juli must know about that."

It makes more sense with the above context, it has a sly play with words, makes proper use of the dash, and signals that George still does not know the real reason Hedda burned the manuscript — which again, leaves the audience to fight for their own conclusions.

The final line of that interaction comes as a serious gut-punch when read with this context. "I feel sorry for Eilert. —Poor man." then qualified by the stage direction of him looking uneasy and thoughtful. Translate that emotional state into behavior and try to reconcile George as happy and the leap is difficult to make. George begins the line by saying he will tell his Aunt Juli everything he has just learned as soon as he can, and immediately switches focus to Eilert. Thinking about the manuscript, all that work and brilliant writing wasted for reasons still unknown. Additionally, Eilert will find it hard, or even impossible, to recover from last night's events, and rebuild his reputation in the community a second time. He then has a change of thought, now focusing on Hedda as if to say, how dare you. In that short scene George sees Hedda's responsibility for the destruction of trust, friendship, love, artistic integrity, family stability-human lives; his behavior must reflect the gravity of such knowledge. All of this has just unfolded because his wife has just dropped atomic bombs on their lives, but George himself sealed Eilert's fate when he left the manuscript in Hedda's care. Not only does George feel an abundance of betrayal but also a certain level of guilt. Looking at it from a behavioral standpoint with that in mind confirms this magnitude of the darkness that washes over George in this scene. 


\section{Dealing with Unfortunate Circumstances}

"A community is like a ship; everyone ought to be prepared to take the helm." -An Enemy of the People

Part of the beauty of live theatre is that pretty much anything can happen, for better or worse. Actors are people and people make mistakes, and when it all happens live and in person, those mistakes just become part of the show. That extends to things that happen off stage as well, an infinite number of things that can occur offstage which the actor, or whomever, has no control over that will affect the show. People have lives and needs outside of the theatre, sometimes the needs of the person interferes with the work of the actor, it just comes with the territory. So while we do what we can to try and prevent those unfortunate occurrences, at times they are unavoidable and we have to find a way to deal with those situations as they come. At the beginning of our second week of runs, on Tuesday, the actress playing Hedda, Nicole, started to feel a bit unwell, but she was not sick or unable to perform so she soldiered on, as artists do-the show must go on and all that. Wednesday night her voice started to deteriorate rapidly during the show, and by the end she sounded quite raspy and had a hard time projecting. (In an unfortunate way, I found the way her voice sounded actually worked in an intriguing way for the character, it had a dark, smokey feel to it that was almost seductive) She made it through the show, thankfully, and at that point all we could do for her was hope resting her voice would allow her to recover enough to perform, and that pushing herself had no lasting effects. In preparation for the worst-case scenario the production team decided that if Nicole could not go on for Thursday's show that we have a back up plan to use the actress playing Berte, Peyton, in the role of Hedda and one of the assistant stage managers, M.J., in the role of Berte. The costume crew fitted them with costumes and stage management made them scripts, and before the show Thursday evening we had a quick rehearsal to go over as much of the blocking as we could with 
the cast member's new roles. For the most part the blocking went smoothly, but at a point near the end of the play when George loses a bit of control of himself with Hedda, he chases her around a bit, and then grabs her. In the interest of safety, we chose to simplify that bit and cut the physical interaction, which made everyone feel more comfortable. Firstly, I would not have to worry about an under-rehearsed physical interaction on stage, and secondly it forced me to dig even deeper to find a way to keep the integrity of the blocking and rehearsal with a different physical action. Anyway, I never saw George as someone who could bring himself to the level of physical altercation, so going to that place always felt just a little bit forced. I can see where from the audience's perspective it would certainly mark a change, though, and ultimately, our goal as actors remains telling the story and sometimes it just feels weird.

Nicole did what she could to rest and soothe her voice, and by call time Thursday night, it improved, although not perfect. But, the show must go on. Stage management placed a water pitcher and glasses on stage for her to utilize throughout the show, and the understudies prepared in case they were called upon. Even with all the planning, we could only do so much to delay the inevitable, though, and thankfully we came prepared. Nicole's relapse came much more rapidly Thursday night and by intermission she simply could not go on, lest she risk serious, potentially lasting, damage to herself. So, in that moment the beauty of theatre reared its magical head and we made the substitutions to the cast; Peyton, took on the role of Hedda, and M.J., took on the role of Berte. Intermission held a bit longer while the two got into costume and did some last minute preparation, and both went on stage with books in hand. Though, having had a day to prepare, they both, impressively, familiarized themselves with their new material quite well. The production manager made an announcement to the audience bringing them up to speed to alleviate confusion as two new people swapped in, and the show continued as planned. The show 
went quite well and had no major hiccups_-aside from a malfunctioning gun which would have happened regardless of who played Hedda. Nicole did recover without serious injury, and we now all have a story of a time when someone had to walk into a role with book in hand. This has happened a few other times so far in my career and even though one never wants to happen, in retrospect it always makes for an interesting memory, and I am glad it did happen.

\section{$\underline{\text { COVID-19 }}$}

\section{"From the time the terrible plague overran the country it has never been quite safe in the mountain here." -Olaf Liljekrans}

Speaking of unwelcome circumstances, our production opened March 5th, 2020, which coincided with the dawning of the global COVID-19 pandemic. By March everyone was quite aware of everything happening across the world, and now beginning to have a big impact on the United States as well; but interestingly enough, West Virginia had not been affected-have to love those geological barriers. They originally scheduled closing for the night after the show Peyton and MJ filled in for, Friday the thirteenth (honestly) and spring break began the day after that. A few days prior I had a discussion with my partner about the implications a serious viral outbreak could have on the theatrical world, but neither of us expected the whole industry to essentially up and disappear. The show must go on right? There is always a way, understudies, books, music tracks, etc; but not in this case. The show had to close; every show had to close. So, likewise, in the interest of safety, and veiled with an excuse of preventing the need to make further accommodations due to Nicole's voice, the powers-that-be decided on Friday afternoon to cancel the Friday show, and end the run where we left off. While not yet fully realizing the severity of 
the situation I felt a bit cheated. I would have liked a ceremonious way to put this character to rest, (for now anyway . . . third time's the charm?) and since the precedent had already been set, I would have enjoyed another performance with fill-ins. While I am always disappointed about canceling a show, and never before have I had a closing show canceled, in retrospect they made the right choice, and that was that; a rather ironic note on which to end the production.

\section{Struggling With a Character}

\section{“Struggle onward, inch by inch." -Brand}

I understand why most people find George ultimately of little consequence in the play; and that he serves only as another person for Hedda to recoil from. He has little support from anyone other than Juli, the majority of conversation about him, especially in his absence, is unflattering, and while he clearly has quirks, an explanation as to the why or where the quirks came from is never provided. Characters who have missing pieces I can't seem to fit together make for the most frustrating work I experience in theatre, especially when I know I have all the parts in front of me but just cannot connect them. playing a character that initially seems underdeveloped forebodes a daunting process.

Firstly, finding indicators in the text becomes all the more scrutinizing, leaving many things up to interpretation; which not only makes things more difficult and leaves the actor feeling less than confident in their choices, but can cause friction between the actor and the director if the two have different interpretations of the less obvious traits. I personally believe that George would not have laid hands on Hedda in anger, but my job is not to question why, but to devise how - and to do so honestly, convincingly, and most importantly, safely. That in turn 
can lead to a further lack of confidence the actor may have in themselves, because ultimately, it is the director who has the final say.

Secondly, when in doubt concerning character development, it drags-out the discovery process and can cause developmental issues with the rest of the cast and even the production as a whole. Spending too much time dwelling on foundational work leaves less time for honing minutia, and can lead to an overall less polished product. Not that anyone else should take blame for an actor struggling to find the right fit for their character, but ultimately, the cast needs to work as a whole. If one actor stumbles, or changes their character's intentions and motivations, it can cause other actors to have to make adjustments, even if everyone else has already found that collaborative equilibrium. No one wants to be that cast member who slows down the process; and in the theatre community reputation matters. Additionally, the audience may struggle with their understanding of the character in the same way as the actor. An actor's job is to bring their character to life and to make what that character says and does completely understandable to the audience, but sometimes, regardless of the depth to which an actor may dive, if on the surface the character seems unimportant, the audience likely will lose their attention to that character early on. This could prove especially disastrous amid a cast of well developed and interesting characters; like, for example, in Hedda Gabler. 


\section{$\underline{\text { Conclusion }}$}

\section{“It's all over, then. I must be going now"-Hedda Gabler}

So from my first reading, to the final line of this thesis I have taken an amazing journey with the character of George Tesman. The first time I played the role, I struggled somewhat to get to where I wanted with the character-if I even got there at all. The second time around, however, I delighted in the thought of revisiting the character. The second reading brought with it a whole new perspective, as it should, and gave me a second chance to find different and more meaningful ways to bring George to life. Different insofar as the second production differed so much to the first, but more importantly, a difference that forced me to stretch myself, apply all the tools and experience I had garnered over the four years since the last production, and make the seemingly banal and droll character of "Hedda's husband" someone who means as much to the play as anyone else. I accepted a personal quest to enrich myself by enriching a character who was habitually undervalued. While on that quest I made many discoveries, learned many things about myself and about theatre, and developed in my craft. I surprised myself by utilizing the Meisner work I thought I had written off, and honed my Michael Chekhov work. I also experienced and strengthened performing in a period play set in one of the most important times in theatrical history, the modern era.

My ability to research and analyze text improved during this process as well. The most convincing actor is one who fights for what they want, faces odds, and takes risks; and the same can be said for a scholar as well. I uncovered more thoughts and feelings about George than I knew I had. I found even more character depth and development than I went in with, concerning the superiority of his character arc, the closeness of his connections with the other characters, and the forces driving his motives. "Ibsen pushed against convention ... and challenged 
audiences" (Allen 10), therefore in order to do him justice I felt like I needed to challenge myself and push against the popular interpretation of Hedda Gabler and its characters. Whether or not I made a convincing George Tesman on stage will remain truly unknown to me, but I can say that I made an improvement portraying the character from one show to the next, and I am happy enough with that. Whether or not I made a convincing argument with this paper that George deserves much more than he is generally awarded, is also unknown to me, but then again, I do not need to know. This is realism, I am not telling anyone what to believe, I am simply providing the story, the reader can make their own decision. 


\section{Bibliography}

“A Study Guide for Henrik Ibsen's Hedda Gabler." Drama for Students, Volume 6. The Gale Group. 1999. Print.

Allen, Brooke. “Unpleasant Ibsen.” New Criterion, vol. 37, no. 10, June 2019, pp. 9- 14 EBSCOhost, search.ebscohost.com/login.aspx?direct=true\&db=a9h\&AN=136596887.

Berlatsky, Noah, "Why Geeks Get Bullied (It's Not Necessarily for Being Geeks).” The Atlantic. Jan. 2013. https://www.theatlantic.com/sexes/archive/2013/01/why-geeks-get-bullied-its-not-necess arily-for-being-geeks/272723/.

Berson, Misha. "Ibsen, Our Contemporary."American Theatre, vol. 35, no. 4, Apr. 2018, pp. 38-43. EBSCOhost,search.ebscohost.com/login.aspx?direct=true\&db=a9h\&AN=128404792.

Chekhov, Michael. To the Actor: On the Technique of Acting. Muriwai Books. 2017. Print.

Cole, Toby. Playwrights on Playwriting. Cooper Square Press. 2001. Print.

Demastes, William W (Ed.). Realism and the American Dramatic Tradition. University of Alabama Press, 1996. ProQuest Ebook Central, https://ebookcentral.proquest.com/lib/wvu/detail.action?docID=1887290.

Egan, Michael (Ed.). Henrik Ibsen. Taylor \& Francis Group, 1997. ProQuest Ebook Central, https://ebookcentral.proquest.com/lib/wvu/detail.action?docID=169702.

Gates, Joanne E. Elizabeth Robbins, 1862-1952. University of Alabama, 1994. Print.

Hansen, T. "Parenthood and Happiness: a Review of Folk Theories Versus Empirical Evidence." Soc Indic Res 108, 29-64 (2012). https://doi.org/10.1007/s11205-011-9865-y.

Heath, Nicola. Why a Baby Won't Save Your Marriage. 2019. https://www.sbs.com.au/topics/voices/relationships/article/2017/08/29/why-baby-wont-sa ve-your-marriage

Ibsen, Henrik. Hedda Gabler. Translated by Jerry Turner. Oregon Shakespeare Festival, 2003. Print.

—. Hedda Gabler. Adapted by Bailey Boudreau. Slipstream Theatre Initiative, 2016. Print.

Lapidos, Juliet. “A Brief Taxonomy of Fictional Academics.” The Atlantic. Jan. 2019.

Ledger, Sally. "Ibsen's Women: The Lady from the Sea, Hedda Gabler and Little Eyolf." Henrik Ibsen, 33-45. Liverpool University Press, 2008. Accessed March 17, 2021. http://www.jstor.org/stable/j.ctv5qdhw5.10. 
Longwell, Dennis. Meisner Sanford, On Acting. Vintage Books. 1987.

Loria, Kakhaber. "The Tragedy of the Exceptional Individual in the Works of Henrik Ibsen andVazha-Pshavela." International Journal of Arts \& Sciences, vol. 8, no. 8, Dec. 2015, pp. 239-245. EBSCOhost, search.ebscohost.com/login.aspx?direct=true\&db=a9h\&AN= 113736884.

Malone, Irina. A defence of Tesman: historiography in Hedda Gabler. Nordlit. 2015.

Means, Richard. "Henrik Ibsen.” Henrik Ibsen, Aug. 2017, pp. 1-2. EBSCOhost, search.ebscohost.com/login.aspx?direct=true \&db=f5h\&AN=15316439\&site=ehost-live \& scope $=$ site.

Orbach, Susie. "What I've Learnt From 40 Years as a Psychotherapist." In Therapy: The Unfolding Story. Profile Books Ltd. 2019

Ossoli, Margaret Fuller. Women in the Nineteenth Century. Edited by Arthur B. Fuller. 2005. Print.

Shaw, George Bernard. The Quintessence of Ibsenism. Brentano’s, 1913. Print.

Stanislaski, Constantin. Building a Character. Translated by Elizabeth Hapgood. Methuen Publishing. 2001. Print.

Teachout, Terry. "Henrik Ibsen, Part 2." Commentary, vol. 147, no. 5, May 2019, pp. 49-52. EBSCOhost, search.ebscohost.com/login.aspx?direct=true\&db=a9h\&AN=136102131.

Valiunas, Algis. “Ibsen's Soulcraft: Considering One of Modernity's Great Dramatists."First Things: A Monthly Journal of Religion \& Public Life, no. 298, Dec. 2019, pp. 1-12. search.ebscohost.com/login.aspx?direct $=$ true $\& \mathrm{db}=\mathrm{a} 9 \mathrm{~h} \& \mathrm{AN}=139639068$. 